\title{
OVERVIEW OF SURFACE-WATER QUALITY IN OHIO'S COAL REGIONS
}

BY

SUSAN WESTOVER AND MICHAEL EBERLE

U.S. GEOLOGICAL SURVEY

WATER-RESOURCES INVESTIGATIONS

OPEN-FILE REPORT 84-4061

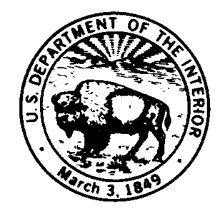

Columbus, Ohio

March, 1987 


\title{
UNITED STATES DEPARTMENT OF THE INTERIOR
}

\author{
DONALD PAUL HODEL, SECRETARY
}

\section{GEOLOGICAL SURVEY}

Dallas. L. Peck, Director

For additional information write to:

\section{District Chief}

U.S. Geological Survey

Water Resources Division

975 West Third Avenue

Columbus, Ohio
Copies of this report can be purchased from:

Open-File Services Section

Western Distribution Branch

U. S. Geological Survey

Box 25425, Federal Center

Denver, Colorado 80225

[Telephone: (303) 234-5888] 


\section{CONTENTS}

Abstract Page

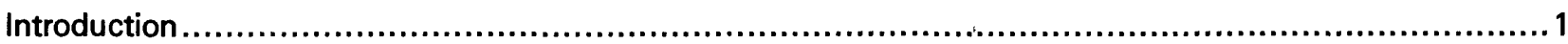

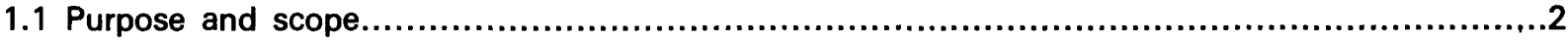

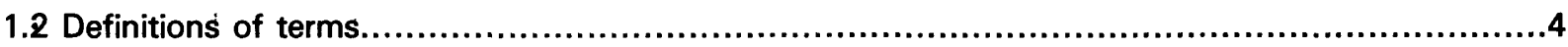

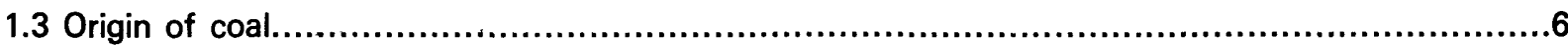

2.0 Coal mining and reclamation in Ohio

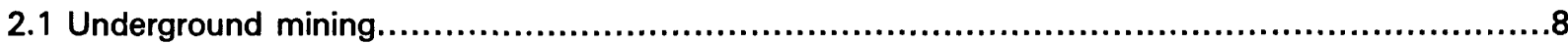

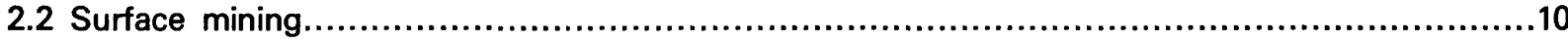

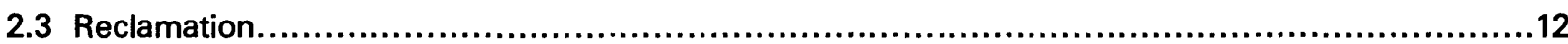

3.0 Surface-water quality

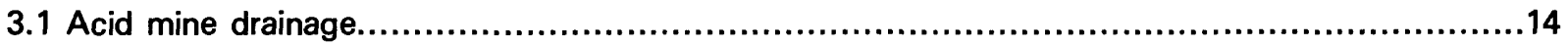

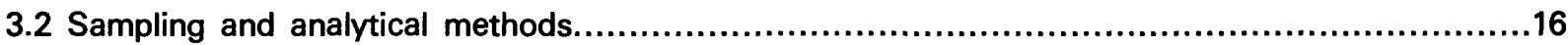

3.3 Results of water-quality analyses

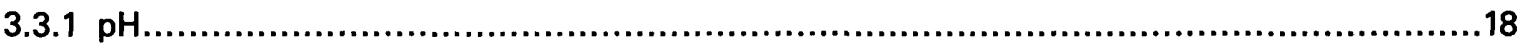

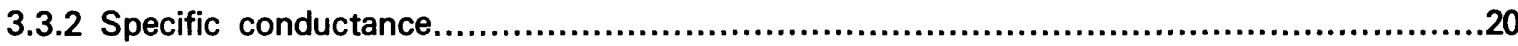

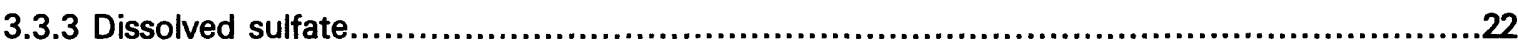

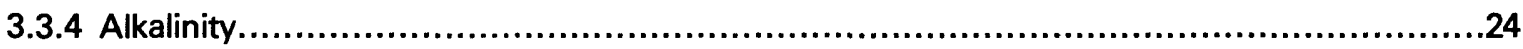

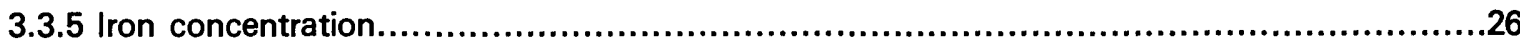

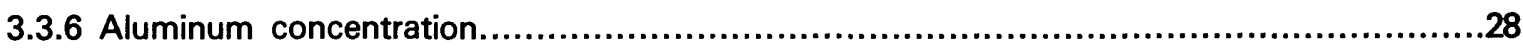

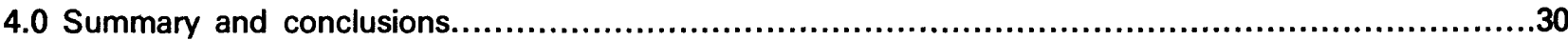

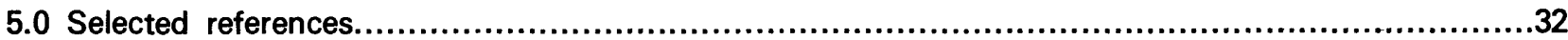




\section{CONVERSION FACTORS AND RELATED INFORMATION}

\section{For the convenience of readers who may want to use the International System}

of Units (SI), the data may be converted by using the following factors:

\begin{tabular}{|c|c|c|}
\hline Multiply inch-pound units & By & To obtain SI units \\
\hline foot (ft) & 0.3048 & moter (m) \\
\hline foot per mile (ft/mi) & .1894 & meter per kilometer $(\mathrm{m} / \mathrm{km})$ \\
\hline ton, short $(2,000 \mathrm{lb})$ & .9072 & megagram (Mg) or metric ton \\
\hline
\end{tabular}




\title{
OVERVIEW OF SURFACE-WATER QUALITY IN OHIO'S COAL REGION
}

\author{
By Susan Westover and Michael Eberle
}

\begin{abstract}
This report is designed to provide the nontechnical audience with some of the results of an "Assessment of Water Quality in Streams Draining Coal-Producing Areas in Ohio," by Christine L. Pfaff and others (published by the U.S. Geological Survey in 1981). The purpose of the assessment was to document the occurrence of certain chemical constituents in streams in Ohio's coal region and determine to what extent the presence of these constituents was related to mining.

Ohio's most productive coal seams are associated with the Allegheny and Monongahela Formation of Pennsylvanian age. These coals were mined by underground methods very early in Ohio's history. Underground mining continues in the state today; however, surface mining now produces significantly more coal. Acid mine drainage from unreclaimed surface and underground mines has affected surfacewater quality in Ohio for many years, and recently has led to establishment of reclamation programs by State and Federal agencies.

underlain by the Allegheny and the Monongahela Formations. Each site represented only one of four landuse types lactive-mine, unmined, abandoned-mine, or reclaimed).

Statistical analysis of data from the unmined, abandoned-mine, and reclaimed sites showed that there were significant differences in $\mathrm{pH}$, specific conductance, alkalinity, and concentrations of sulfate and aluminum among abandoned-mine and unmined sites. Reclaimed sites had average $\mathrm{pH}$ values and aluminum concentrations similar to those of unmined sites. Average specific conductance and sulfate concentrations were about the same for reclaimed and abandoned-mine sites, but were significantly lower at unmined sites; specific conductance and sulfate concentration, in fact, proved to be reliable indicators of basins that had been disturbed by mining. Alkalinity was significantly different for all three land uses, the highest values being found at reclaimed sites. The relationships revealed by this study may be useful in designing future water-quality sampling programs in Ohio's coal region.
\end{abstract}

In their assessment of Ohio's coal region, Pfaff and others sampled 150 sites in small watersheds 


\title{
1.0 INTRODUCTION \\ 1.1 PURPOSE AND SCOPE
}

\section{REPORT DESCRIBES WATER QUALI IY IN STREAMS DRAINING COAL-PRODUCING AREAS IN OHIO}

\author{
This report discusses the results of the scientific study, "Assessment of Water Quality in \\ Streams Draining Coal-Producing Areas of Ohio;" the report, which is \\ intended for readers who may not have technical back rounds, also \\ includes brief discussions of Ohio geology and mining technology.
}

This report summarizes and provides to the nontechnical audience some of the results of the scientific study, "Assessment of Water Quality in Streams Draining Coal-Producing Areas in Ohio," by Christine L. Pfaff and others (1981). The assessment was begun in 1975, with support of the U.S. Environmental Protection Agency, to provide information on several aspects of coal mining, mine reclamation, and water resources in Ohio.

The assessment consisted of two phases. The objectives of phase 1 were 'to document the occurrence of certain inorganic and organic constituents in waters of the coal-mining regions [of Ohio] and to determine if the concentrations of those constituents were related to coal mining' (Pfaff and others, 1981, p. 2). A total of 150 stream sites were chosen for sampling (fig. 1.1-1), each of which was sampled twice. Certain water-quality properties and chemical constituents were measured on site; water samples also were bottled and sent to laboratories for further analysis. These 150 sites were selected such that only one of four landuse categories-active mining, abandoned mines, reclaimed mines, or unmined areas - was represented within the drainage area of each site.
Some of the data collected during phase 1 were analyzed statistically to determine if the levels of certain properties and constituents differed significantly among unmined areas, abandoned-mine areas, and reclaimed areas (data from active-mine basins were not included); analyses also were done to find out if there were any significant differences between sites that are underlain by two bedrock formations present in eastern Ohio.

Phase 2 of the assessment was a more detailed study of four sites that had been sampled during phase 1. Because the findings of phase 2 were much the same as those of phase 1, phase 2 is not discussed.

For the benefit of readers who are unfamiliar with the origin of coal or with coal mining in Ohio, several sections of this report are devoted to background material on geology and mining.

It is hoped that the information presented in this report will be useful to residents of eastern Ohio and to others who are interested in issues related to coal production, land reclamation, and water quality. 


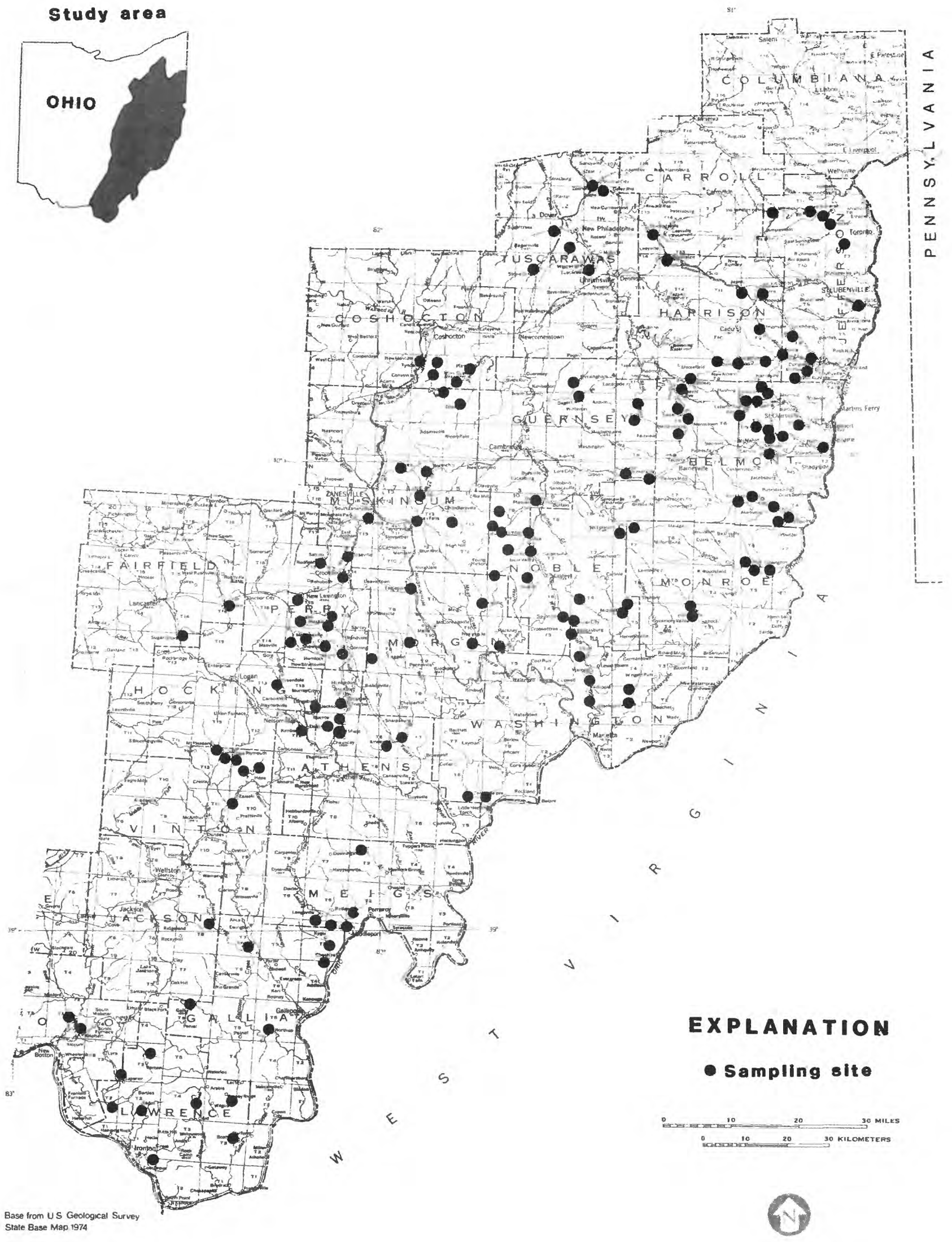

Figure 1.1-1 Location of stream sampling sites (from Pfaff and others, 1981) 


\subsection{INTRODUCTION (Continued) 1.2 DEFINITION OF TERMS}

\section{TERMS USED IN THIS REPORT ARE DEFINED}

\section{Some of the technical terms used in other sections of this report are defined below.}

Abandoned-mine is a surface or underground mine that has been deserted and in which further mining is not planned.

Acid mine drainage - is an acidic solution that can form if air and standing water are present in a surface or underground coal mine; acid mine drainage contains large concentrations of sulfates and iron.

Alkalinity - is the capacity of a solution to neutralize acid.

Area mining - is a type of surface mining used where the coal seam is relatively close to the surface and the topography is level or gently rolling.

Basin (drainage) - is "a part of the surface of the earth that is occupied by a drainage system, which consists of a surface stream or a body of impounded surface water together with all tributary surface streams and bodies of impounded water" (Langbein and Iseri, 1960).

Bench-is " $(a)$ the surface of an excavated area at some point in the overburden between the coal or material being mined and the original surface of the ground on which machines can sit, move, and operate; (b) a working road or base below a highwall as in contour stripping for coal" (Camplin, 1965).

Bituminous coal-is soft coal, dark brown to black in color, that has a high content of carbonaceous matter.

Coal seam - is a "layer, vein or deposit of coal; a stratigraphic part of Earth's surface containing coal" (Camplin, 1965).
Contour mining - is a type of surface mining used where the terrain is hilly; mining begins at the coal outcrop and cuts are made in a series around the hillside.

Dip - is the downward sloping of rock strata away from the plane of the horizon.

Dog hole - is a small excavation made directly in to a coal seam; the surface opening to a mine.

Erosion - is "the movement of any substance or material by a natural element" (Camplin, 1965).

Formation - is a body of rock that is uniform enough in character to be considered a unit.

Highwall - is "the vertical wall, consisting of the coal face and the overlying rock and soil strata of the mining site; the final cut of a stripping operation" (Camplin, 1965).

Infiltration - is "the flow of fluid into a substance through pores or small openings" (Langbein and Iseri, 1960).

Lignite-is brownish-black coal that is in termediate between peat and bituminous coal.

Mined land - is any land area that is actively being excavated either by surface or underground methods.

Neutralize - is to add an acid to a basic solution or to add a base to an acidic solution so that the resultant is neutral.

Outcrop - is part of a geologic formation or structure that is exposed at the Earth's surface. 
Overburden - is "the earth, rock, and other materials that lie above a natural coal deposit" (Camplin, 1965).

Peat-is a brown or brownish-black mass of semicarbonized plant materials that has undergone decomposition in a wet environment; an early stage in the development of coal.

Pennsylvanian - is "a division of late Paleozoic geologic time, extending from 320 to 280 million years ago. . . named for outcrops of coal-bearing rock formations in Pennsylvania" (Lapedes, 1978).

Period - is "a unit of geologic time constituting a subdivision of an era; the fundamental unit of the standard geologic time scale" (Lapedes, 1978).

Permian - is "the last period of geologic time in the Paleozoic era, from 280 to 225 million years ago" (Lapedes, 1978).

$p H$ - is a scale commonly used to express the degrees of acidity of alkalinity; $\mathrm{pH}$ of 7 is the point of neutrality at which there is neither acidity nor alkalinity. As acidity increases, the $\mathrm{pH}$ value decreases, and as alkalinity in creases, the $\mathrm{pH}$ value increases.

Pyrite - is an iron-sulfide mineral that has a metallic appearance and is commonly found in sandstone, shale and coal.
Reclamation - is "the process of reconverting mined land to other forms of productive uses" (Camplin, 1965).

Sedimentary rock - is "rock formed by consolidated sediment deposited in layers, . . . stratified rock" (Lapedes, 1978).

Soluble-means capable of being dissolved.

Specific conductance - is a measure of the ability of a substance to conduct electrical current; in this report, specific conductance refers to the amount of current conducted by a cubic centimeter of water at a temperature of 25 degrees Celsius.

Spoil-is "all overburden material removed from over the coal after it is either deposited back into the area from which the coal has been removed or on undisturbed land" (Camplin, 1965).

Unconsolidated material - is "loosely arranged or unstratified sediment whose particles are not cemented together" (Lapedes, 1978).

Unmined land - is any land area that is not or has not been disturbed by mining. 


\title{
1.0 INTRODUCTION (Continued) 1.3 GEOLOGY OF OHIO COAL DEPOSITS
}

\section{OHIO COAL IS FOUND PRIMARILY IN PENNSYLVANIAN-AGE FORMATIONS}

\author{
Coal beds in Ohio are found primarily within the Allegheny and Monongahela \\ Formations of Pennsylvanian age that crop out \\ in the eastern part of the State.
}

The coal fields of Ohio are located in the eastern part of the State (fig. 1.3-1). They extend as far north as Geauga County, as far south as Lawrence County, and as far west as Scioto County.

Ohio coals are found in rocks of Pennsylvanian and Permian age. These rocks are sedimentary; they were deposited in a river-and-delta environment between 320 and 225 million years ago. The rock layers consist of an alternating sequence of sandstone, shale, mudstone, coal, and limestone. These rocks have been categorized as the Pottsville, Allegheny, Conemaugh, and Monongahela Formations of Pennsylvanian age, and the Dunkard group of Pennsylvanian and Permian age (Brant and DeLong, 1960, p. 23). Most of the economically important coal beds are in Penn- sylvanian formations. Because the rock layers dip to the southeast at a slope of 25 to 40 feet per mile, the formations crop out in roughly parallel bands (fig. 1.3-1).

The Allegheny and Monongahela Formations contain coal beds that are especially productive; thus, most coal mines in Ohio are within the outcrops of these two formations (Pfaff and others, 1981, p. 5). The rock types of the two formations differ considerably; the Monongahela Formation contains much more limestone and calcareous ("limey") shale than does the relatively noncalcareous Allegheny Formation (Pfaff and others, 1981, p. 17, 27). 


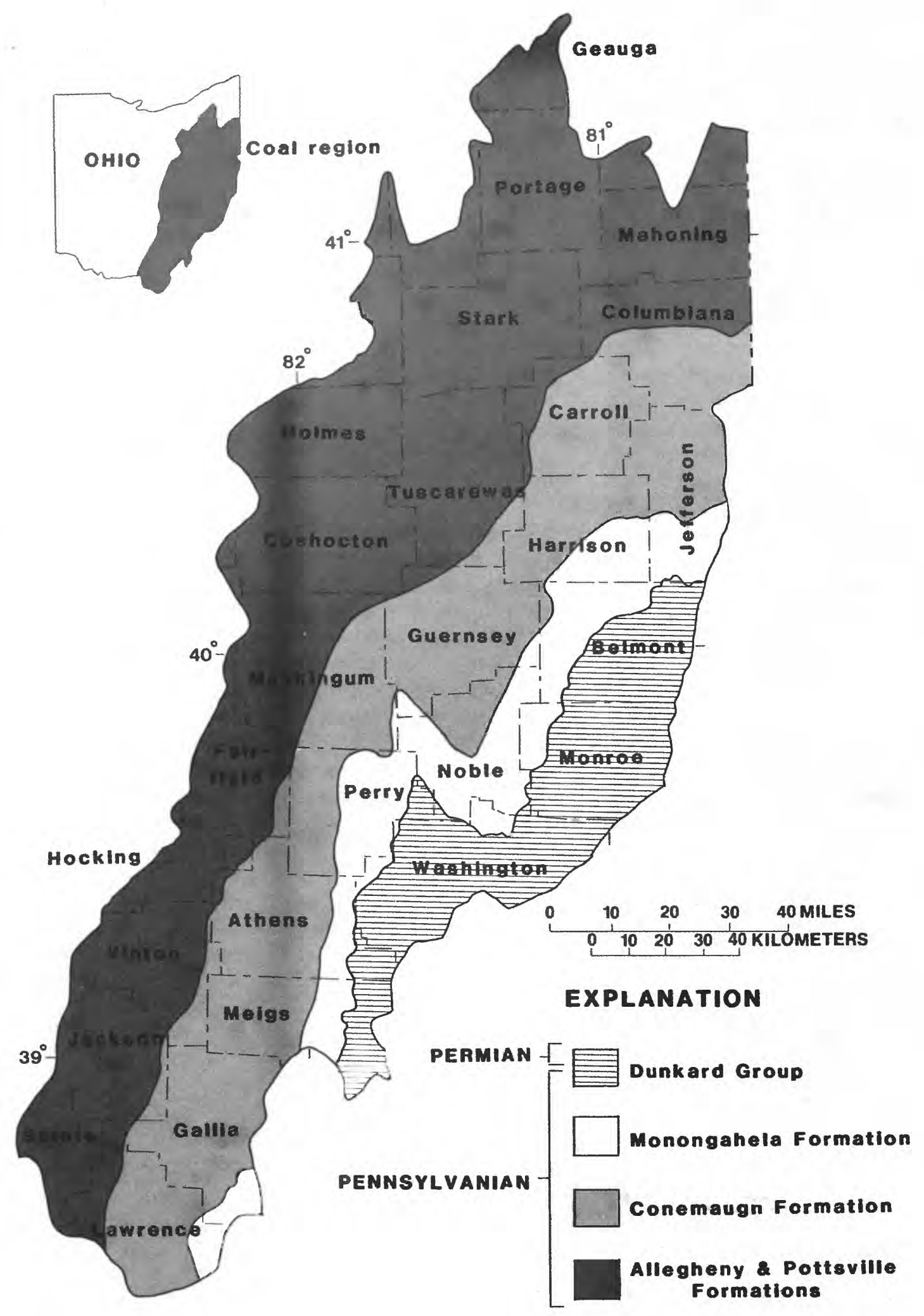

Figure 1.3-1 Approximate boundaries of the Pottsville, Allegheny, Conemaugh, and Monongahela Formations, and the Dunkard Group (from Bownocker, 1981) 


\title{
2.0 COAL MINING AND RECLAMATION IN OHIO 2.1 UNDERGROUND MINING
}

\section{THREE TYPES OF UNDERGROUND MINES ARE USED IN OHIO}

\author{
Coal is obtained from either drift, slope, or shaft mines, depending \\ on the location of the coal seam relative to the land surface.
}

Numerous technological advances in coal mining have taken place since coal first was mined in Ohio. Among the first miners in eastern Ohio were farmers who used coal from local outcrops to heat their homes. The farmers would excavate coal near the surface with picks and shovels; later, especially during the winter months, "dog holes" were constructed. By 1840, there were small drift mines in Ohio. Coal was removed by shovel and loaded onto sleds, which were then pulled to the outside by men and women. Soon small wagons and wooden rails took the place of sleds, and dogs and ponies began pulling the wagons.

Underground drift, slope, and shaft mines all are used to mine coal in Ohio today (fig. 2.1-1). Drift mining is usually the most cost effective of the three mining types, as the opening into the mine is made directly into the coal seam.

Where the coal seam lies far below the surface, either a slope or a shaft mine can be used. Slope mines are constructed on an incline through the rock layers to the coal seam.

The shaft mine also is constructed through the rock strata to the coal seam. In this type of mine, however, a vertical shaft lined with concrete extends from the land surface to the coal seam. The coal is then hoisted out of the shaft by means of electrically powered steel cables. Shaft mines are preferred where overburden is thick.

Three methods for extracting the coalcontinuous mining, conventional mining, and longwall mining - are used in underground mines in Ohio. The continuous miner is a machine that breaks up coal at the working face of the mine and automatically loads the coal onto a haulage truck or conveyor belt. In conventional mining, holes are drilled into the working face and explosives are set in these holes; after the coal is exploded, it crumbles and is then loaded either directly onto a conveyor belt or loaded by machine onto a shuttle car. In longwall mining, blocks of coal up to 27 inches thick are removed from the working face in a single pass of the mining machinery.

Tables 2.1-1 and 2.1-2 present coal-production data for Ohio underground mines from 1978 through 1981.
Table 2.1-1. Number of working underground mines in Ohio

[Data from Ohio Division of Mines, 1978-80, and Ohio Department of Natural Resources, Division of Geological Survey, 1983]

\begin{tabular}{lcccc}
\hline Type & 1978 & 1979 & 1980 & 1981 \\
\hline Drift & 14 & 10 & 9 & 8 \\
Slope & 10 & 9 & 7 & 5 \\
Shaft & 5 & 6 & 6 & 6 \\
Total & 29 & 25 & 22 & 19 \\
\hline
\end{tabular}

Table 2.1-2. Underground coal production in Ohio

[Data from Ohio Division of Mines, 1978-80, and Ohio Department of Natural Resources Division of Geological Survey, 1983; all figures represent short tons per year]

\begin{tabular}{lcccc}
\hline Method & 1978 & 1979 & 1980 & 1981 \\
\hline Continuous & $8,352,342$ & $9,716,197$ & $12,479,571$ & $9,070,091$ \\
Conventional & $3,016,789$ & $4,838,833$ & $2,093,505$ & $1,522,643$ \\
Hand & 20,075 & - & - & - \\
Longwall & - & - & - & $1,507,524$ \\
Total & $11,389,206$ & $14,555,030$ & $14,573,076$ & $12,100,258$ \\
\hline
\end{tabular}




\section{Surface}

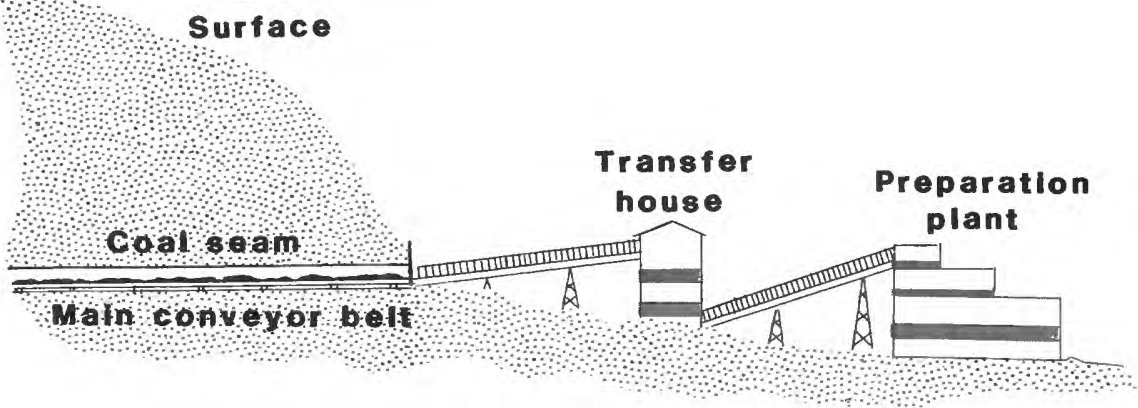

A. Drift mine

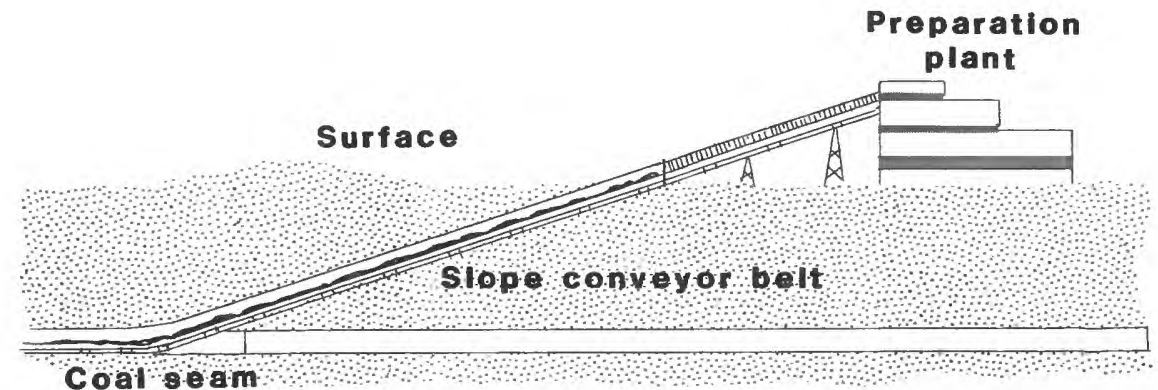

B. Slope mine

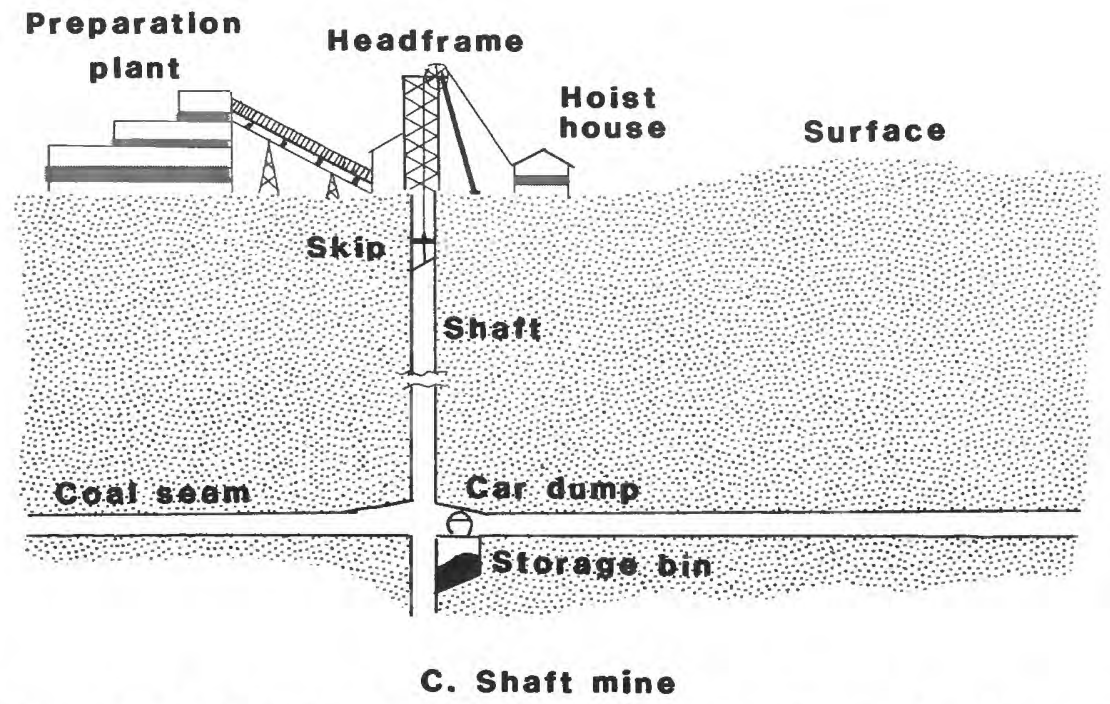

Figure 2.1-1Types of underground mines (from Cassidy, 1973; reproduced by permission) 


\title{
2.0 COAL MINING AND RECLAMATION IN OHIO (Continued) 2.2 SURFACE MINING
}

\section{SURFACE MINING ACCOUNTS FOR MOST OF THE COAL PRODUCED IN OHIO}

\author{
Area, contour, and auger types of surface mining produce \\ about two-thirds of the coal mined in Ohio today.
}

Coal production by surface mines in Ohio was first recorded in 1914; in some counties, a considerable amount of coal was being surface mined as early as World War I (Collins, 1976). By World War II, surfacemining production began to increase rapidly with the advent of improved and larger excavating and hauling equipment. Eventually, coal production from surface mines surpassed that from underground mines. Approximately two-thirds of the coal mined in Ohio today is produced by surface-mining methods.

Because of Ohio's diverse topography, several types of surface-mining procedures are used. Area mining (fig. 2.2-1) generally is used in places where the coal seam is approximately level with the surface. The overburden (overlying soil and rock material) is removed from a series of parallel pits, beginning at the coal outcrop or at the point where the coal is closest to the surface; mining progresses into areas of thicker overburden. Spoil (excavated overburden) from each new cut is replaced in the preceding pit.

Where the terrain is extremely hilly, as is true in much of eastern Ohio, contour mining generally is used (fig. 2.2-2). Contour mining, like area mining, begins either at the outcrop or where coal is closest to the surface. Cuts are made in a series around the hillside. As each pit is excavated, the overburden is replaced into the preceding pit. Overburden from the first cut is transported off the working site and is later used to fill the last pit, thus avoiding an exposed highwall when mining is completed.

Coal remaining in the last highwall is sometimes recovered by auger mining (fig. 2.2-3) if it is not possible to recover more coal by any other method. In auger mining, a boring machine fitted with auger bits cuts into a vertical coal face and brings coal out of the borehole. Auger mining can be used following normal area and contour mining operations. It is capable of removing coal to a penetration depth of 200 feet.

Methods of removing overburden and excavating the coal are diverse. Draglines, large shovels, and bulldozers remove overburden, whereas smaller shovels, loaders, augers, and excavators remove the coal. Draglines are used in areas where the overburden is thick and unstable and the coal seam is relatively thin. Large shovels are used in areas where the overburden is thin. After the overburden has been removed by dragline or large shovel, smaller shovels and frontend loaders complete the mining process by loading the coal into haulage trucks. 


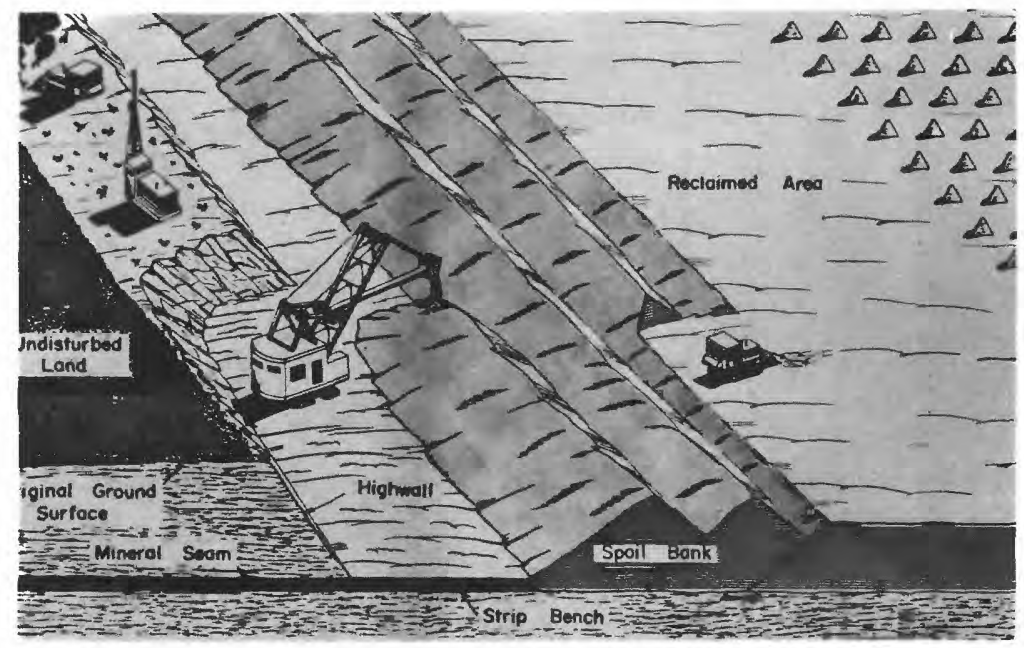

Figure 2.2-1 Area mining (from U.S. Environmental Protectlon Agency, 1973)

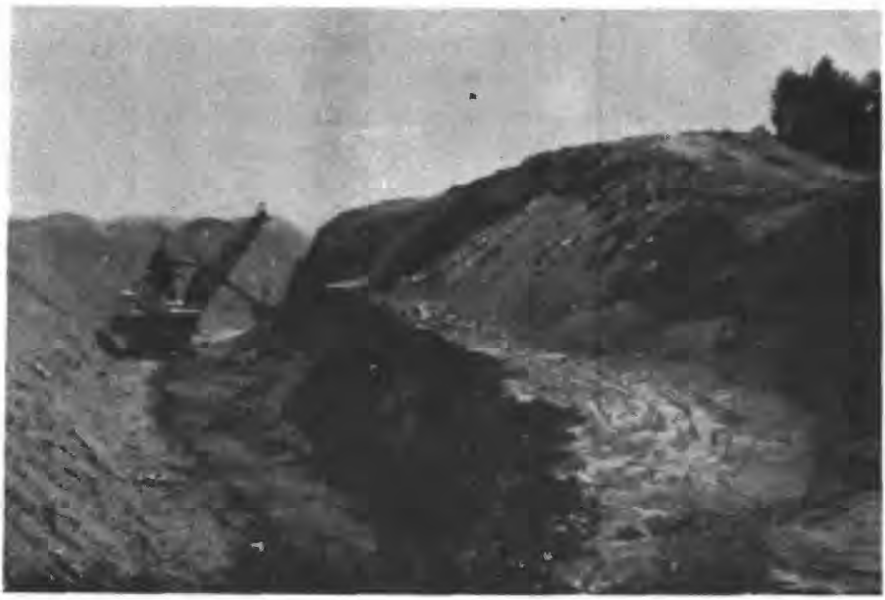

Figure 2.2-2 Contour mining

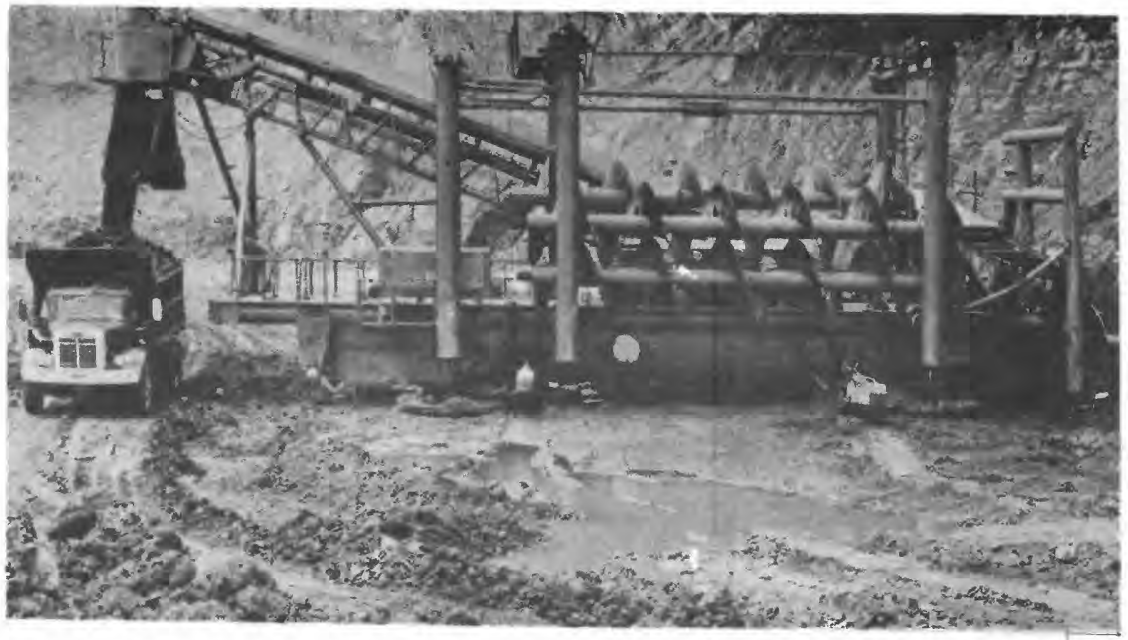

Flgure 2.2-3 Auger mining (from Camplin, 1965)

2.0 COAL MINING AND RECLAMATION IN OHIO (Continued) 


\subsection{COAL MINING AND RECLAMATION IN OHIO (Continued) 2.3 RECLAMATION}

\section{RECLAMATION PROCEDURES SPECIFIED BY STATE AND FEDERAL REGULATIONS}

\section{Current Federal and State programs have made reclamation a routine part of mining, and have provided money for reclamation of abandoned mine lands.}

\begin{abstract}
Abandoned surface and underground mines can be found throughout the eastern third of Ohio. Because abandoned mines provide favorable conditions for acid mine drainage, they can cause degradation of the quality of nearby streams. Moreover, unreclaimed surface mines generally have little aesthetic appeal and negligible potential for subsequent use.
\end{abstract}

Reclamation of abandoned underground mines in Ohio generally has consisted of sealing entrances to drift mines. Because entrances to drift mines are at roughly the same elevations as flooded mine rooms, considerable quantities of acid mine drainage can discharge from these entrances and eventually migrate to streams. Remedial mine sealing first took place in Ohio in the 1930's as the result of a Federal program to reduce acid pollution of streams in the Ohio River basin (Pfaff and others, 1981, p. 2). Similar programs are still being carried out today by the Ohio Department of Natural Resources, Division of Reclamation.

Laws requiring reclamation of surface-mined lands were enacted in Ohio in 1948. At that time, mine operators were required to post bonds before mining an area. In most cases, however, forfeiture of the bond was cheaper than the cost of reclamation. It was also - apparent that the laws did not provide for restoration of land and water to usable conditions. In 1972, Ohio laws governing reclamation procedures were made more stringent, bonds became more expensive, and penalties for disregarding the law were severe OOhio Board on Unreclaimed Strip Mined Lands, 1974, p. 2).

After the passage of the U.S. Surface Mining Control and Reclamation Act of 1977 (Public Law
95-87), Ohio modified its 1972 laws and regulations to conform to the Federal law and regulations. Reclamation is now a routine part of surface mining operations in Ohio. In addition, money from Federal fees on surface-mined coal is provided to the Ohio Department of Natural Resources, Division of Reclamation, for use in reclaiming abandoned mine lands.

There are several elements fundamental to all surface-mine reclamation operations. The first element is construction of drainage channels and sedimentholding ponds. These sedimentation ponds, built below the mining site on existing streams, aid in retaining coal dust, silt, and mineral pollutants that have been carried from the spoil and into the stream.

The second element in reclamation is burial of the highly pyritic spoil. Spoil is usually unconsolidated material; it is therefore easily eroded by the effects of water and the wind. Most mining companies today begin burying the spoil shortly after the coal from the first cut has been mined.

The last elements in reclamation are addition of topsoil, contouring, and revegetation of the spoil banks (figs. 2.3-1 and 2.3-2). Revegetation is essential to the overall quality of the reclamation not only because it lessens erosion but also for aesthetic appeal. Reclaimed lands frequently are seeded with grasses, alfalfa, clover, and birdsfoot. These plants help to stabilize the spoil, and increase the soil's $\mathrm{pH}$ and water-holding capacity. 


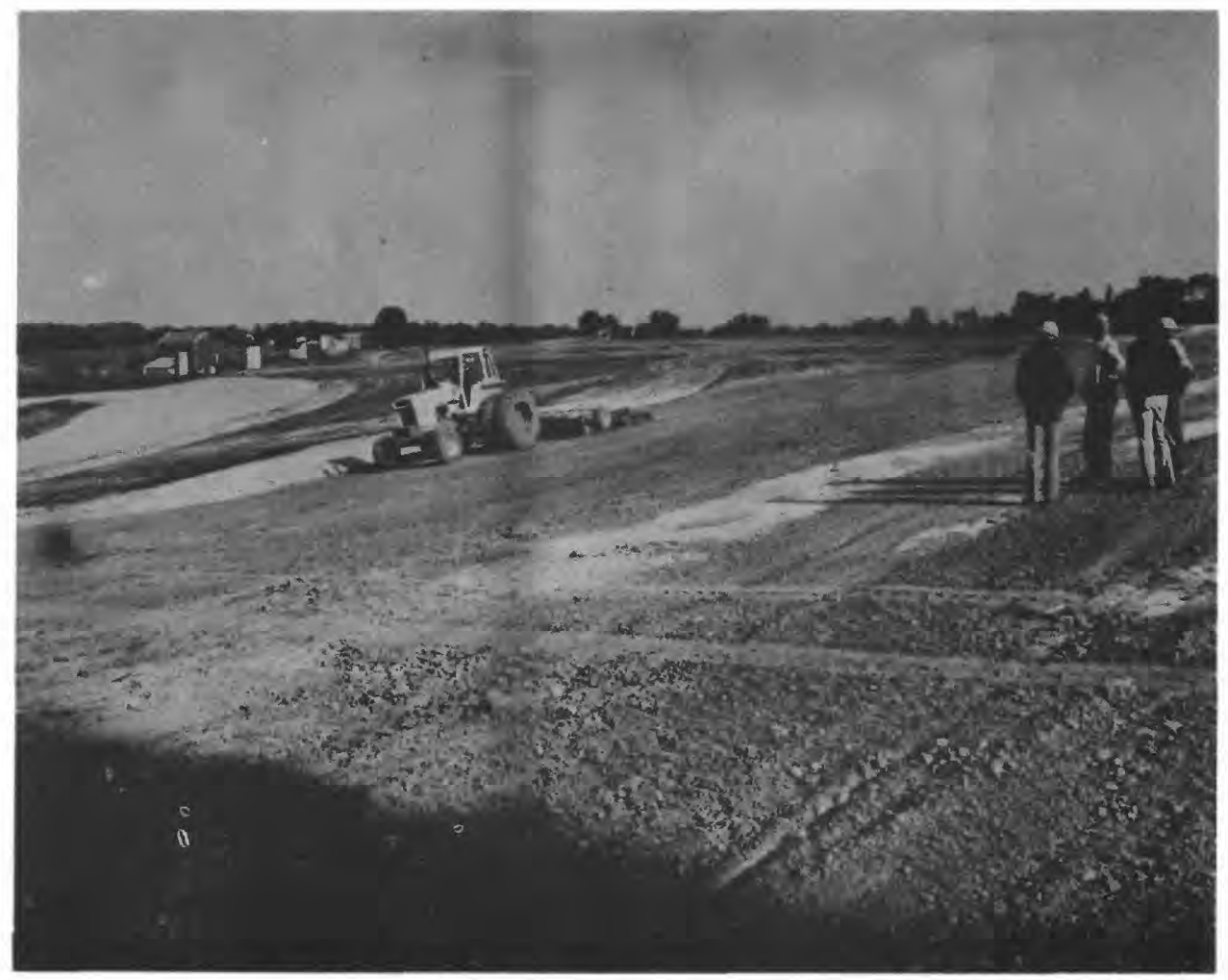

Figure 2.3-1 Soll preparation on regraded mine land

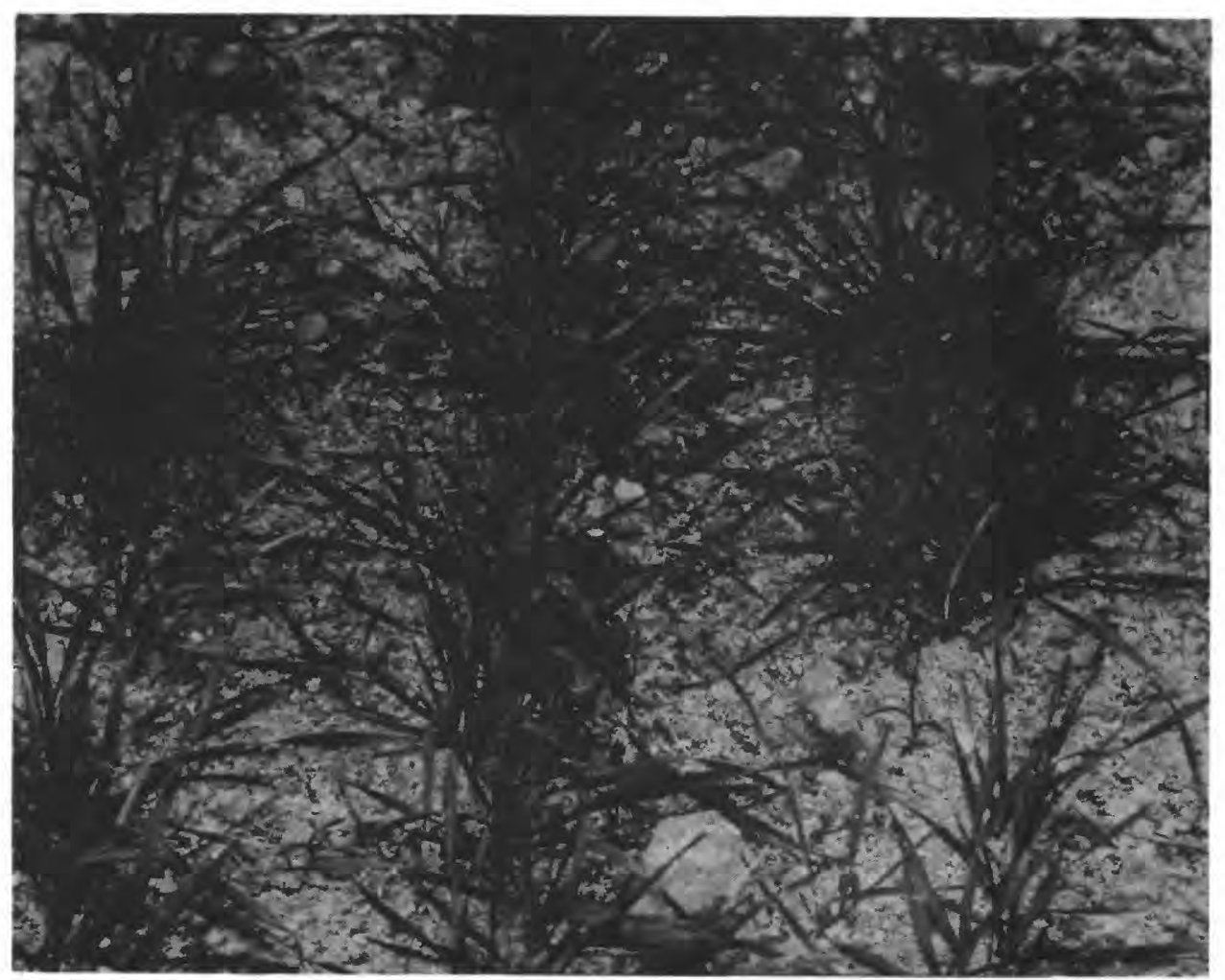

Flgure 2.3-2 Revegetated mine land

2.0 COAL MINING AND RECLAMATION IN OHIO (Continued) 


\title{
3.0 SURFACE-WATER QUALITY 3.1 ACID MINE DRAINAGE
}

\section{ACID MINE DRAINAGE IS A CHEMICAL PRODUCT OF PYRITE, AIR, AND WATER}

\author{
Acid mine drainage, which develops when the mineral pyrite is exposed \\ to air and water, is characterized primarily by low $\mathrm{pH}$ and \\ high concentrations of iron and sulfate.
}

Acid mine drainage is a common water-quality problem throughout Ohio's coal region, especially in areas where abandoned mines are numerous. Acid mine drainage is characterized primarily by low $\mathrm{pH}$ (high acidity), and high concentrations of iron and sulfate.

Acid mine drainage develops when the mineral pyrite is exposed to air and water. Pyrite is the chemical compound iron disulfide, which has the chemical formula FeS. Pyrite is found in shales and sandstones that lie above coal seams. It is also present within the coal and is distinguished by its shiny, metallic appearance. It is the sulfur in pyrite that reacts with hydrogen and oxygen in air and water to form sulfuric acid and iron sulfate. The iron sulfate continues to chemically react with hydrogen and oxygen to yield iron hydroxide. Iron hydroxide is an insoluble reddish-yellow solid that can be seen covering stream beds in areas where acid mine drainage is severe.

Abandoned mines are the main source of acid mine drainage because conditions are particularly favorable for its production. In abandoned underground mines, ground water infiltrating into a mine room may pass over exposed coal and pyrite, and react with air in the mine to produce acid water. As the acid water seeps to the outside, it may react with the atmosphere and produce more acid and iron hydroxide (fig.3.1-1).

Before regulations governing reclamation procedures were strictly enforced, spoil from underground mines was brought to the surface, piled up, and left exposed. Precipitation that fell on and percolated through these exposed piles reacted with pyrite and created acidic water that drained into nearby streams.

Acid mine drainage can also form in surface mines if runoff from precipitation is allowed to stand in exposed working pits (fig. 3.1-2). To avoid this, most active surface mines have downstream holding ponds and drainage control channels within the mine. 


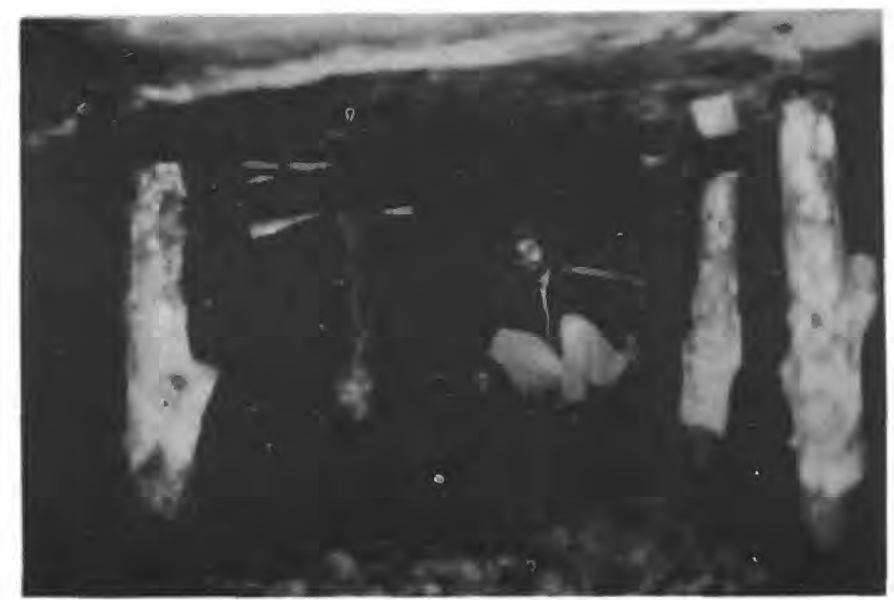

A. Partlally flooded mine room

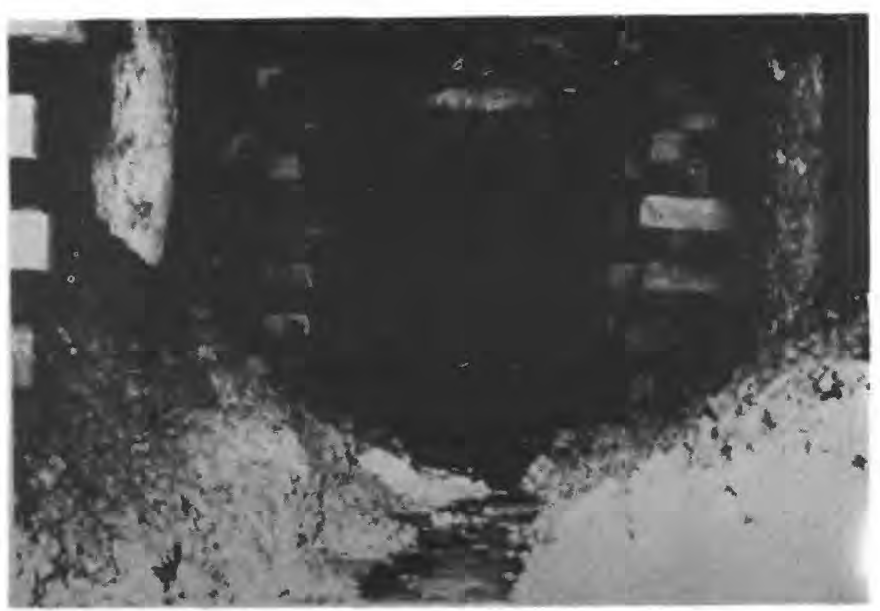

B. Acldic water discharging from mine entrance

Figure 3.1-1 Conditions contributing to acid mine drainage from an underground mine.

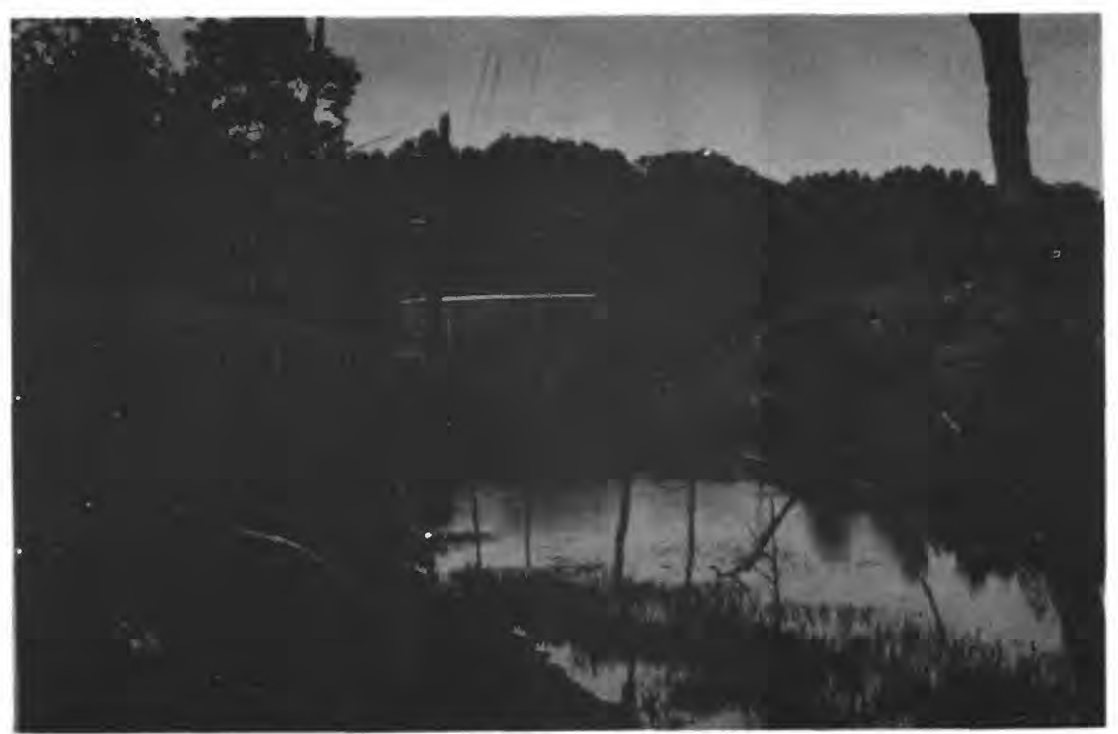

Figure 3.1-2 Standing water adjacent to spolls in a surface mine. 


\title{
3.0 SURFACE-WATER QUALITY (Continued) 3.2 SAMPLING AND ANALYTICAL METHODS
}

\section{WATER-QUALITY DATA WERE ANALYZED STATISTICALLY}

\author{
Specific conductance, $\mathrm{pH}$, alkalinity, and concentrations of iron, aluminum, and \\ sulfate were determined for 150 sites; the data were analyzed statistically \\ with respect to land use and geological factors.
}

Water-quality samples were collected at 150 stream sites in Ohio's coal region. Samples were collected in late spring and autumn during periods of low flow (Pfaff and others, 1981, p. 10).

The water samples were collected in plastic bottles at a point in the stream where the water was well mixed and free flowing. This type of sampling technique is known as "grab" sampling (Brown, 1974). Figure 3.2-1 shows a sample bottle and sampling technique. A meter was used to measure the specific conductance at or near the point in the stream where the grab samples were taken (fig. 3.2-2). Alkalinity and $\mathrm{pH}$ determinations were made in the field vehicle with equipment shown in figure 3.2-3. Water samples were also bottled and sent to a U.S. Geological Survey laboratory to be analyzed for sulfate, sulfide, chloride, phenol, total organic carbon, aluminum, arsenic, chromium, copper, iron, manganese, mercury, and zinc.

The results of the chemical analyses were examined to see if any of the properties and constituents were influenced by either the mining-related land use lunmined, abandoned-mine, or reclaimed; active-mine basins were not considered) or the underlying geologic formation (Allegheny or Monongahela).

Only 6 of the 16 properties and constituents appeared to be influenced enough by land use or geology to warrant further study. These were $\mathrm{pH}$, specific conductance, sulfate, iron, alkalinity, and aluminum.

A statistical technique known as analysis of variarice was used to determine whether there were "significant" differences between these properties and constituents with respect to land use and geology. 'Significance' is the probability that a statistical test will show the average values for data sets to be different when, in fact, they are not. The level of significance selected by Pfaff and others was 5 percent, which means that there would be only a 5 percent chance of incorrectly declaring two data sets to be different.

Where analysis of variance indicated that differences existed, additional statistical tests were used to determine which land-use or geological categories differed. 


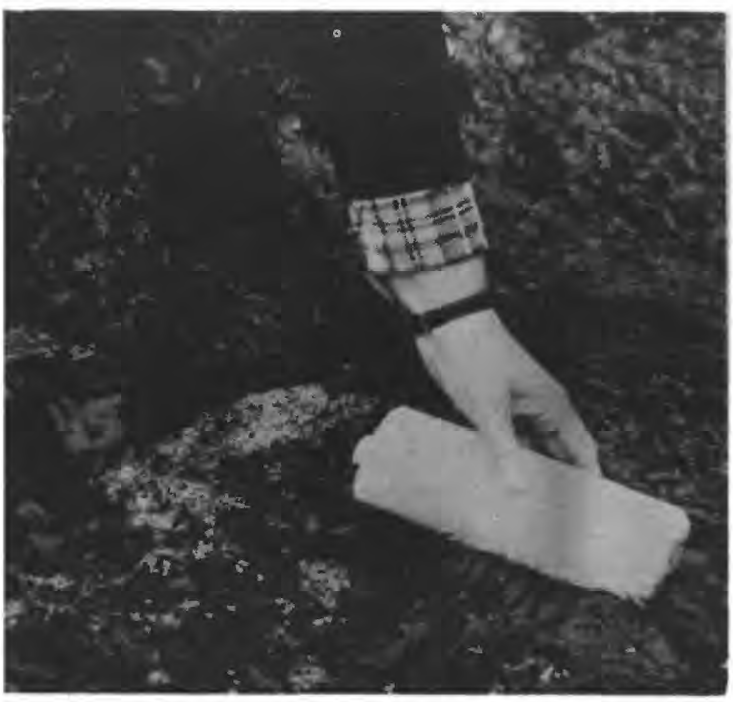

Figure 3.2-1 "Grab" sample

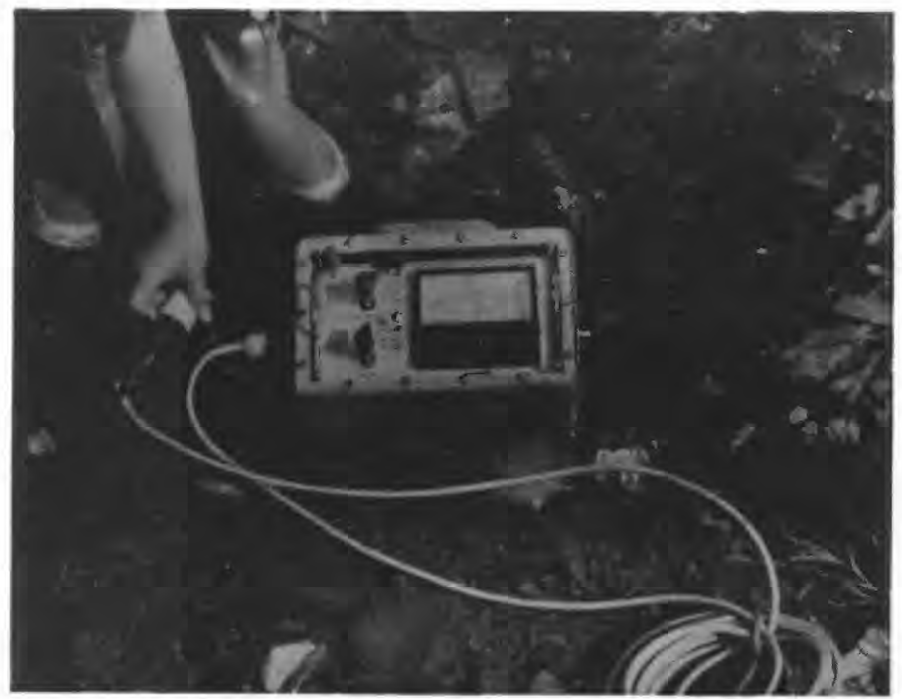

Figure 3.2-2 Measurement of specific conductance

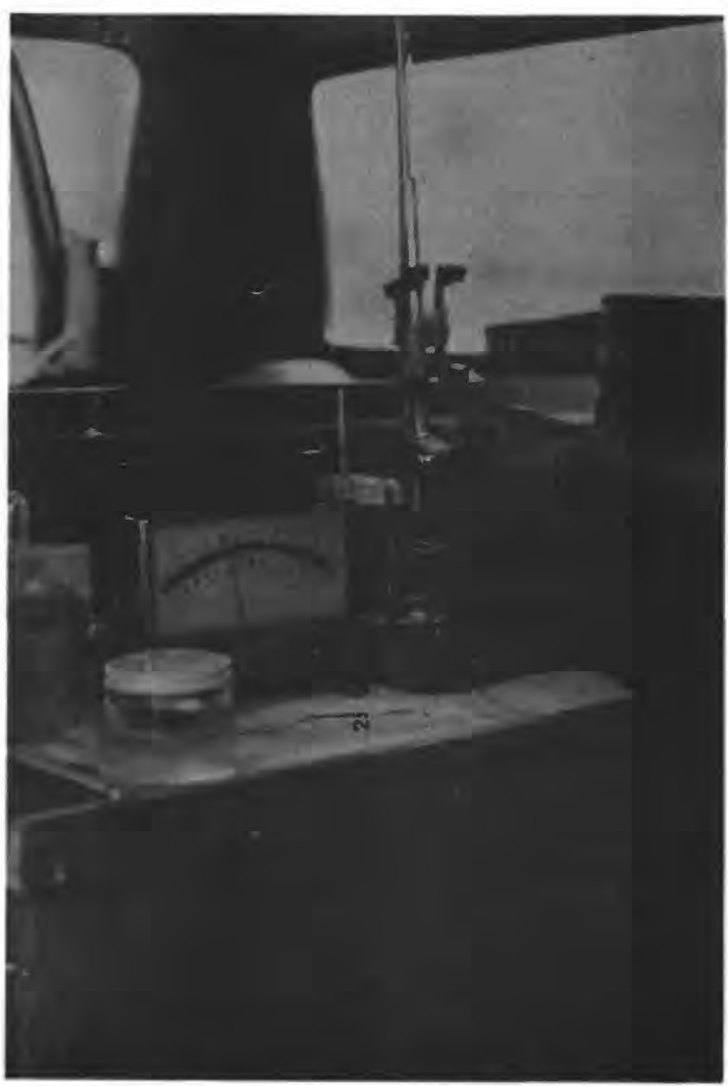

Figure 3.2-3 Apparatus for field determination of $\mathrm{pH}$ and alkalinity

3.0 SURFACE-WATER QUALITY (Continued) 


\subsection{SURFACE-WATER QUALITY (Continued) 3.3 RESULTS OF WATER-QUALITY ANALYSES $3.3 .1 \mathrm{pH}$}

\section{pH VALUES WERE LOWEST IN STREAMS THAT DRAIN ABANDONED-MINE BASINS}

$\mathrm{pH}$ in the study area ranged from 1.9 in an abandoned-mine basin to 8.9 in an unmined basin.

The $\mathrm{pH}$ scale is divided into increments from 0 through 14; a $\mathrm{pH}$ of 7 represents a neutral solution (fig. 3.3.1-1). If there is an abundance of hydrogen ions in a solution, the solution is acidic and will have a $\mathrm{pH}$ less than 7 . However, if the solution is deficient in hydrogen ions, the solution is basic and will have a $\mathrm{pH}$ greater than 7 . The $\mathrm{pH}$ of natural, undisturbed streams normally is between 6.0 and 8.0 (Hem, 1970). Table 3.3.1-1 compares some of the occurrences and effects of different $\mathrm{pH}$ levels in the range found in Ohio's coal region.

The $\mathrm{pH}$ values reported by Pfaff and others (1981) ranged from 1.9 (drainage issuing directly from an abandoned underground mine) to 8.9 (a stream in an unmined basin). In general, low $\mathrm{pH}$ values were found in basins where abandoned surface and underground mines predominated, whereas the $\mathrm{pH}$ values in reclaimed and unmined basins were slightly higher than neutral (fig. 3.3.1-2). The average* $\mathrm{pH}$ for abandoned-mine basins was 4.8 ; the average for both reclaimed and unmined basins was 7.4

The $\mathrm{pH}$ values of streams in basins overlying the Allegheny Formation were slightly lower than those in

\footnotetext{
*The average $\mathrm{pH}$ values reported here and in other sections of the report were determined by converting $\mathrm{pH}$ values to hydrogen-ion concentrations, taking the average, and converting back to $\mathrm{pH}$.
}

basins overly ing the Monongahela Formation (fig. 3.3.1-2): averages for all land uses were 5.1 and 7.0 respectively. Rocks of the Monongahela Formation are high in calcium carbonate, a compound that neutralizes acid.

The U.S. Environmental Protection Agency (1976), p. 178 ) has suggested a lower limit of 5.0 and an upper limit of 9.0 for $\mathrm{pH}$ in domestic water supplies to prevent corrosion or scaling of water-system components and to avoid problems with water treatment. (Note: Water-quality limits for domestic water supplies are discussed in this and following sections to explain the possible effects of certain properties and constituents. This does not imply that the streams sampled by Pfaff and others actually are used as water sources; most of them probably are not.) Although a pH as low as 6.0 is considered unlikely to be directly toxic to fish, a limit of 6.5 has been suggested as safe for fish and the organisms upon which they feed IU.S. Environmental Protection Agency, 1976, p. 180.

Table 3.3.1-1 Occurrence and effects of selected $\mathrm{pH}$ values [Modified from Rainwater and Thatcher, 1960]

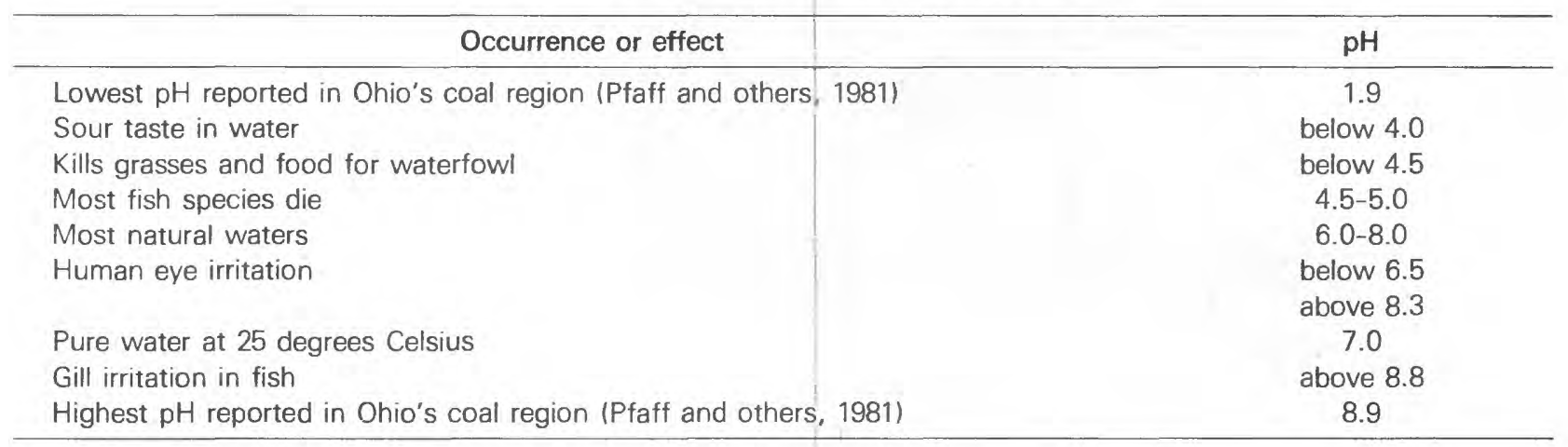



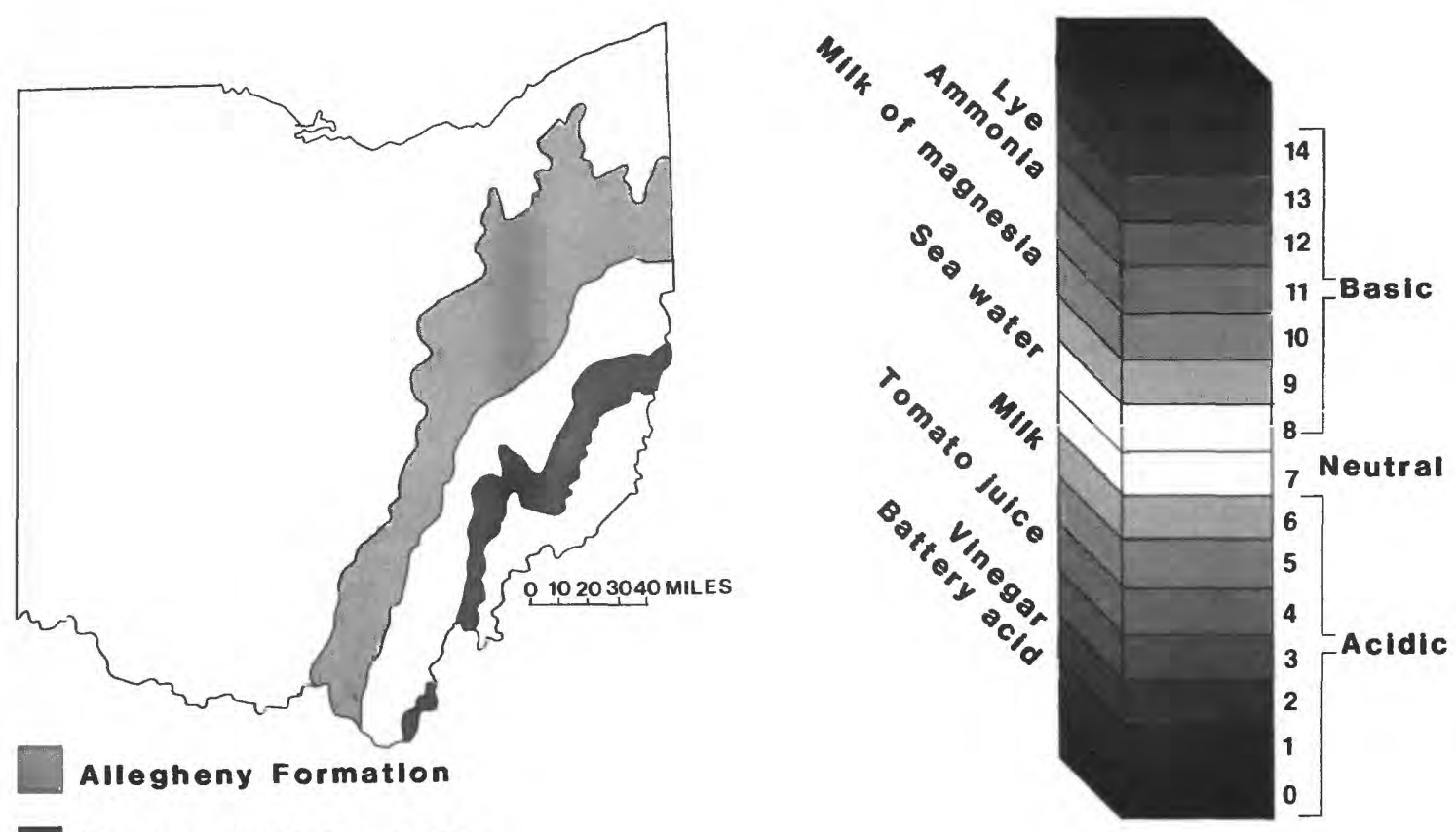

Monongahela Formation

Approximate boundaries of Allegheny and Monongahela Formations

Figure 3.3.1-1The pH scale

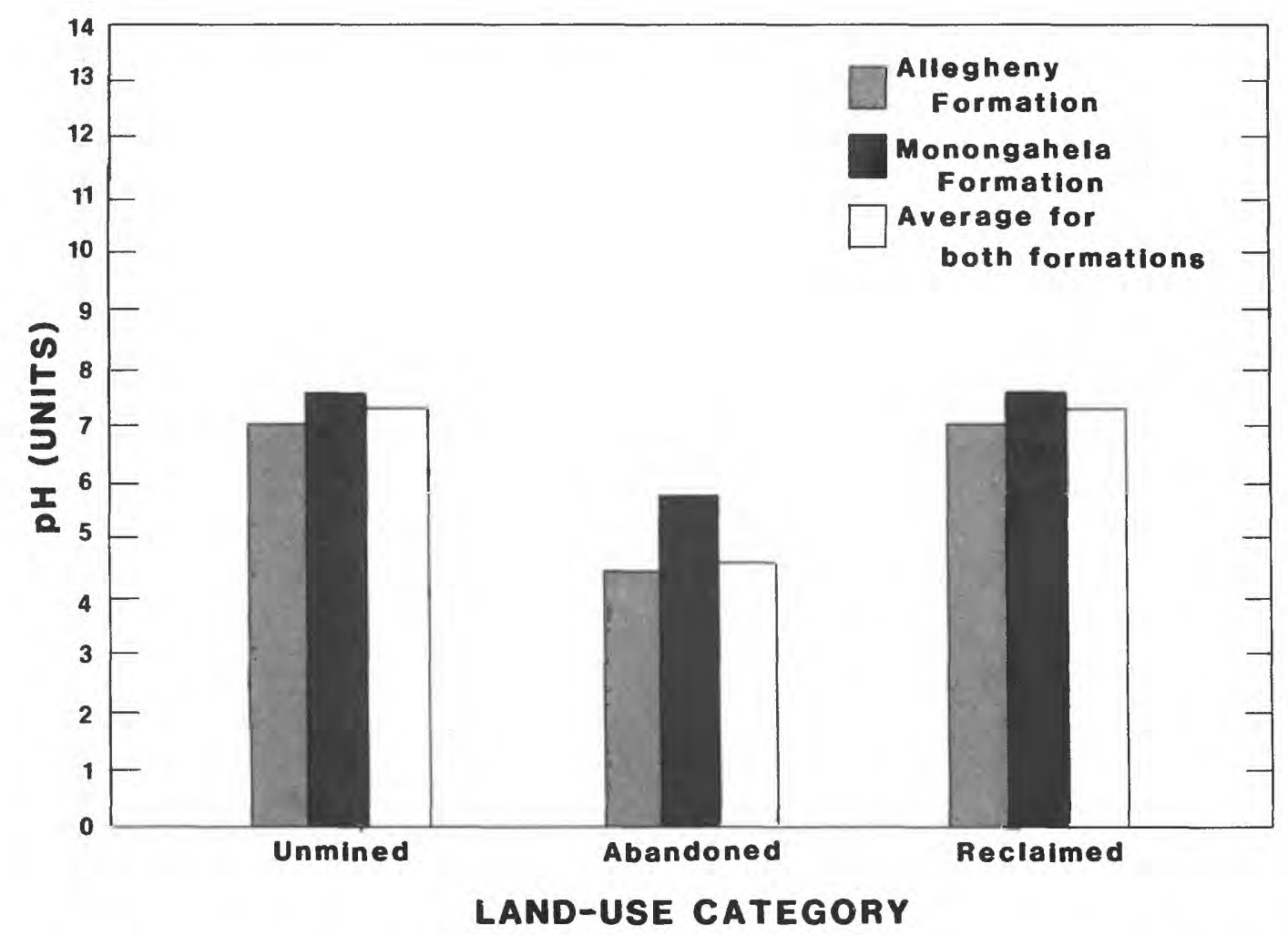

Figure 3.3.1-2 Average pH values (data from Pfaff and others, 1981) 


\title{
3.0 SURFACE WATER QUALITY (Continued) 3.3 RESULTS OF WATER-QUALITY ANALYSES (Continued) 3.3.2 Specific conductance
}

\section{SPECIFIC CONDUCTANCE WAS HIGHEST FOR ABANDONED-MINE SITES}

\author{
Average specific conductances by land-use category \\ (in micromhos per centimeter) were: Unmined, 426; \\ reclaimed, 1,406; and abandoned-mine, 1,512.
}

Specific conductance is a measure of the ability of a solution to conduct an electrical current. In water, the specific conductance increases as the concentration of dissolved substances increases; specific conductance, therefore, can be used as an approximate measure of total dissolved solids concentration and as a general indicator of overall water quality. Specificconductance values, in micromhos per centimeter $(\mu \mathrm{mho} / \mathrm{cm})$, are presented for several different types of water in table 3.3.2-1.

Pfaff and others (1981) found that average specific conductances of streams in abandoned-mine and reclaimed basins 11,512 and $1,406 \mu \mathrm{mho} / \mathrm{cm}$, respectively) were significantly higher than those of streams in unmined basins $(426 \mu \mathrm{mho} / \mathrm{cm})$. Conductances of more than $800 \mu \mathrm{mho} / \mathrm{cm}$ generally were found in basins disturbed by mining. Specific conductance is one of the best indicators of whether there had ever been mining within the drainage area of a given site (Pfaff and others, 1981, p. 27).

Average conductance for reclaimed basins in the Monongahela Formation, $1,570 \mu \mathrm{mho} / \mathrm{cm}$, was higher than the $840-\mu \mathrm{mho} / \mathrm{cm}$ average for reclaimed basins in the Allegheny Formation (fig. 3.3.2-1). This probably is due to the greater amounts of easily dissolved calcium carbonate minerals in the Monongahela Formation.

Table 3.3.2-1 Average specific conductances for water [From Hem, 1970, and Rainwater and Thatcher, 1960]

\begin{tabular}{|c|c|}
\hline Type of water & $\begin{array}{l}\text { Specific conductance in micromhos } \\
\text { per centimeter at } 25^{\circ} \mathrm{C}\end{array}$ \\
\hline Sea water.................... & 50,000 \\
\hline Pure water at $25^{\circ} \mathrm{C} \ldots \ldots \ldots \ldots . . . .$. & 0.05 \\
\hline Distilled water........................ & 1.0 \\
\hline Most natural waters in the U.S. & ......... less than 1,000 \\
\hline
\end{tabular}




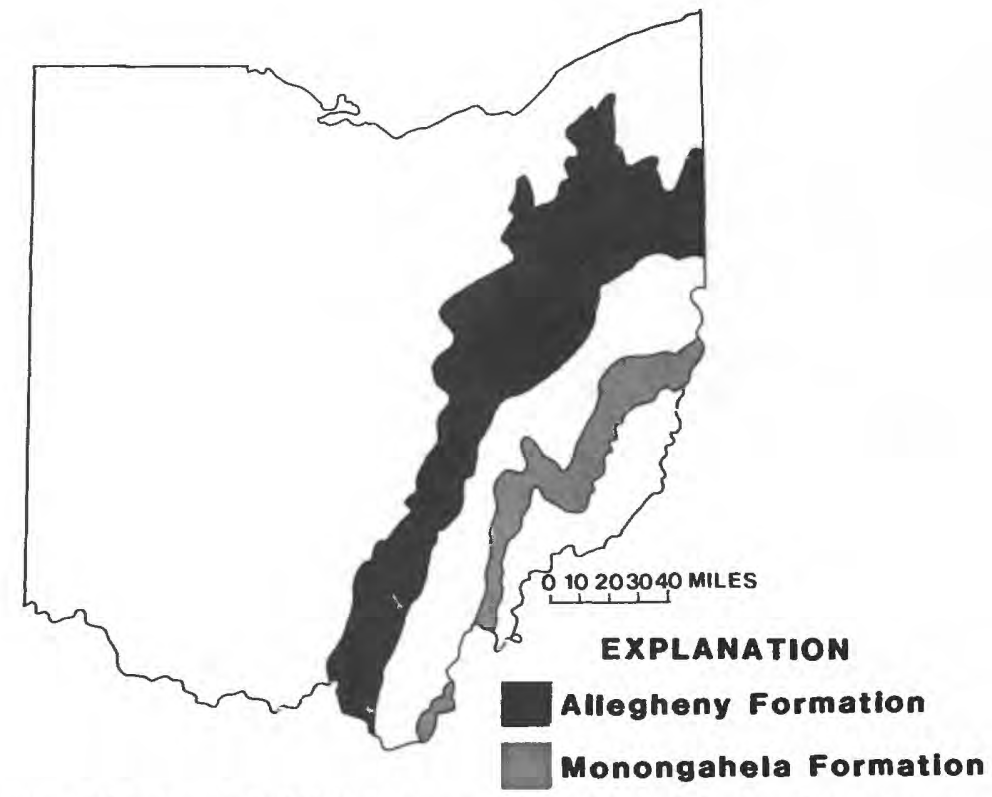

Approximate boundaries of Allegheny and Monongahela Formations

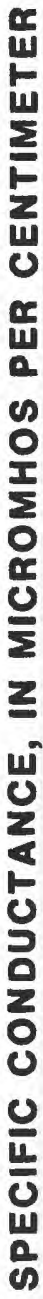

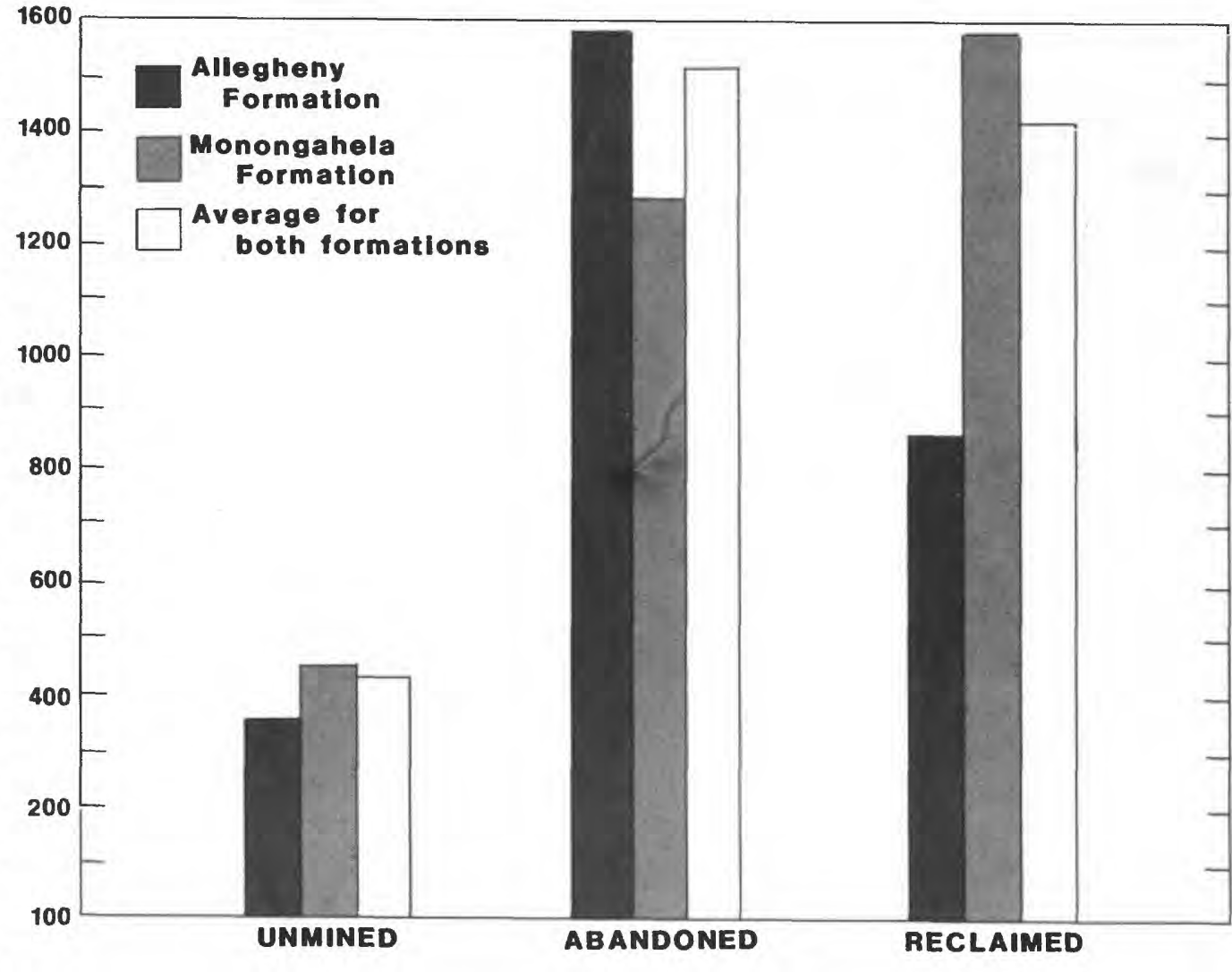

LAND-USE CATEGORY

Figure 3.3.2-1 Average specific conductances (data from Pfaff and others, 1981)

3.0 SURFACE-WATER QUALITY (Continued)

3.3 RESULTS OF WATER-QUALITY ANALYSES (Continued) 


\title{
3.0 SURFACE-WATER QUALITY (Continued) \\ 3.3 RESULTS OF WATER-QUALITY ANALYSES (Continued) \\ 3.3.3 Sulfate concentration
}

\section{SULFATE CONCENTRATION IS A RELIABLE INDICATOR OF BASINS DISTURBED BY MINING}

\author{
All sulfate concentrations greater than 250 milligrams per liter \\ were attributable to mining disturbances.
}

Sulfate concentration is a reliable indicator of basins disturbed by mining las is specific conductance). Sulfate can enter water as a result of the oxidation of the mineral pyrite. Oxygen from air and water reacts with the iron and sulfur in pyrite, and sulfate is released.

Sulfate concentrations in the Ohio coal region ranged from $22 \mathrm{mg} / \mathrm{L}$ (milligrams per liter) in two unmined basins to $7,000 \mathrm{mg} / \mathrm{L}$ in an abandoned-mine basin. In unmined basins, sulfate concentrations averaged $75 \mathrm{mg} / \mathrm{L}$. In abandoned-mine basins, concentrations averaged $579 \mathrm{mg} / \mathrm{L}$. Concentrations in reclaimed basins averaged $480 \mathrm{mg} / \mathrm{L}$ (fig. 3.3.3-1).
Pfaff and others (1981) found that all sulfate concentrations in excess of $250 \mathrm{mg} / \mathrm{L}$ at study sites in the Ohio coal region were attributable to mining disturbances.

The U.S. Environmental Protection Agency (1976, p. 205) has suggested a limit of $250 \mathrm{mg} / \mathrm{L}$ for domestic water supplies; however, no maximum level has been included in Federal regulations to date UU.S. Environmental Protection Agency, 1977). Sulfate concentrations in excess of $250 \mathrm{mg} / \mathrm{L}$ are known to have a laxative effect on some people, but this effect is more common in occasional users of high-sulfate water than it is for regular users. 


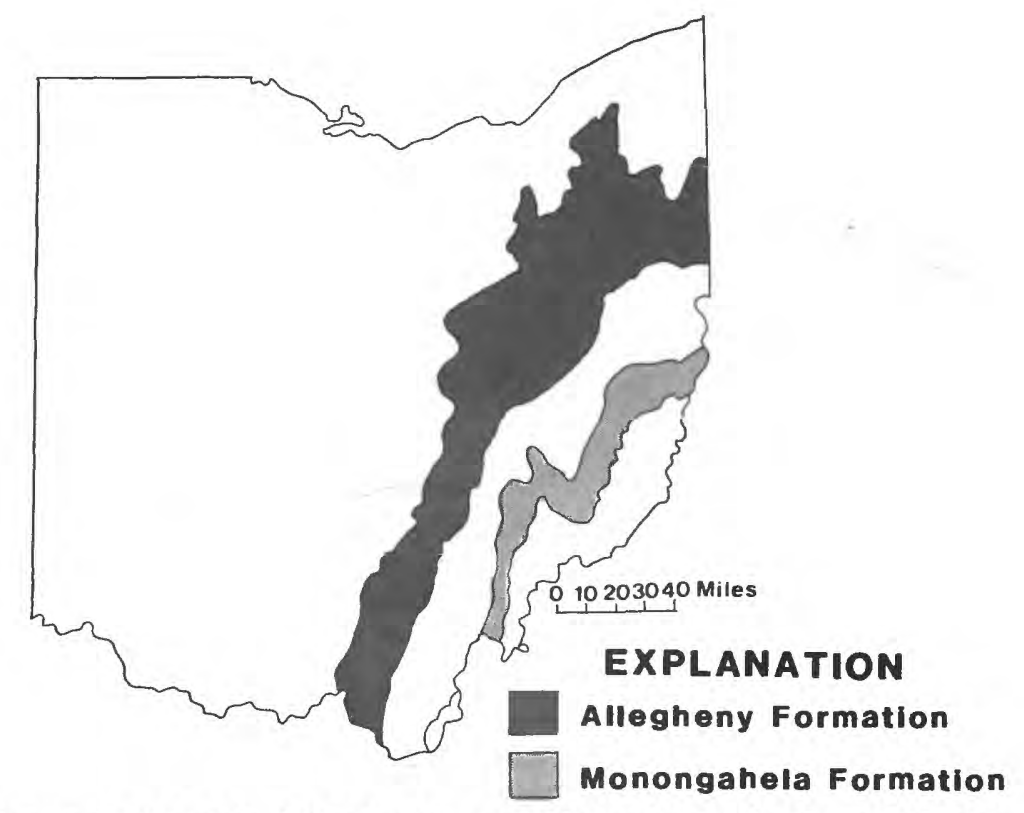

Approximate boundaries of Allegheny and Monongahela Formations.

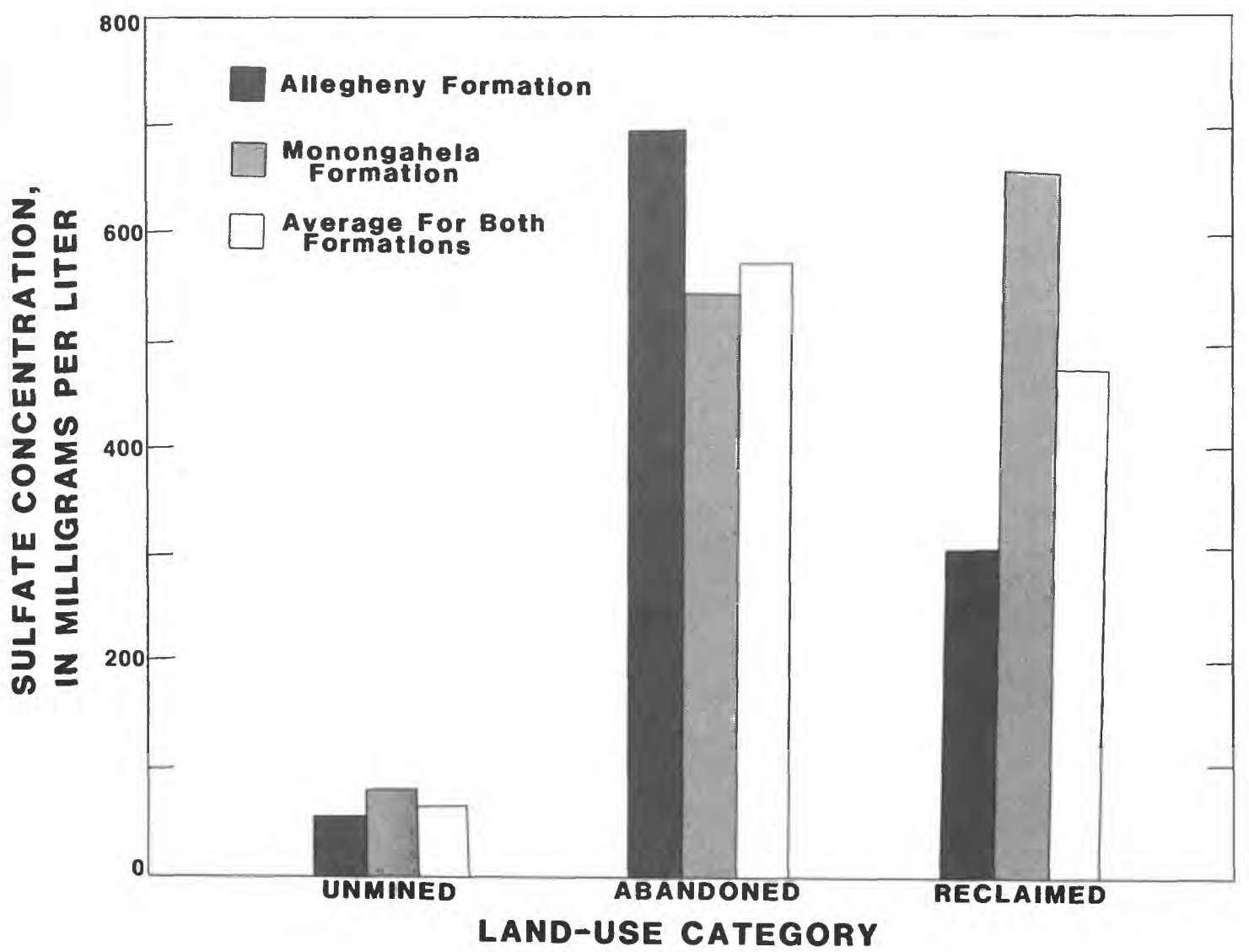

Figure 3.3.3-1 Average sulfate concentrations (from Pfaff and others, 1981). 


\title{
3.0 SURFACE WATER QUALITY (Continued) \\ 3.3 RESULTS OF WATER-QUALITY ANALYSES (Continued) \\ 3.3.4 Alkalinity
}

\section{ALKALINITY CONCENTRATIONS ARE INFLUENCED BY LAND USE AND GEOLOGY}

\author{
Significant differences were found among the average alkalinity concentrations \\ for reclaimed, unmined, and abandoned basins, and between \\ average concentrations for the Allegheny \\ and Monongahela Formations.
}

Alkalinity is the capacity of a solution to neutralize an acid. Most of the alkalinity in natural waters is in the form of carbonate and bicarbonate ions. Neutralization occurs when carbonate and bicarbonate are free to react with the hydrogen ions in acidic water. This process increases the $\mathrm{pH}$ value. Alkalinity concentrations in the study area ranged from $1 \mathrm{mg} / \mathrm{L}$ (milligram per liter) in an abandoned basin to $525 \mathrm{mg} / \mathrm{L}$ in a reclaimed basin.

There were significant differences between the average alkalinity concentrations for reclaimed, unmined, and abandoned-mine basins. The average concentrations for reclaimed basins, $189 \mathrm{mg} / \mathrm{L}$, was higher than the 131- $\mathrm{mg} / \mathrm{L}$ average for unmined basins (fig. 3.3.4-1). Pfaff and others (1981) suggest this may be due to greater infiltration capacity and increased surface-area exposure of soil and underlying rock after reclamation.

The average alkalinity for abandoned-mine basins was $42 \mathrm{mg} / \mathrm{L}$; this low concentration reflects the neutralization reactions taking place between carbonate and bicarbonate ions and acid mine drainage.

With respect to geology, higher alkalinity concentrations were found in basins underlain by the Monongahela Formation (average, $161 \mathrm{mg} / \mathrm{L}$ ) than in basins underlain by the Allegheny Formation (average, $40 \mathrm{mg} / \mathrm{L}$ ). Rocks of the Monongahela Formation contain more carbonate than do rocks of the Allegheny Formation. 


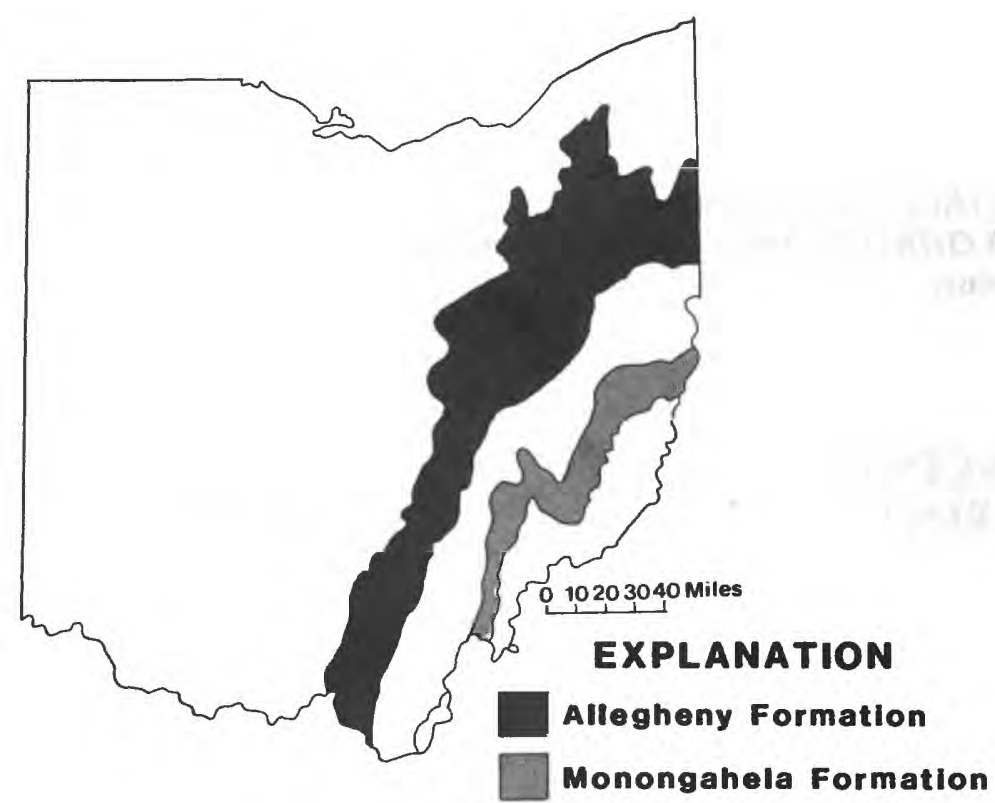

Approximate boundaries of Allegheny and Monongahela Formations.

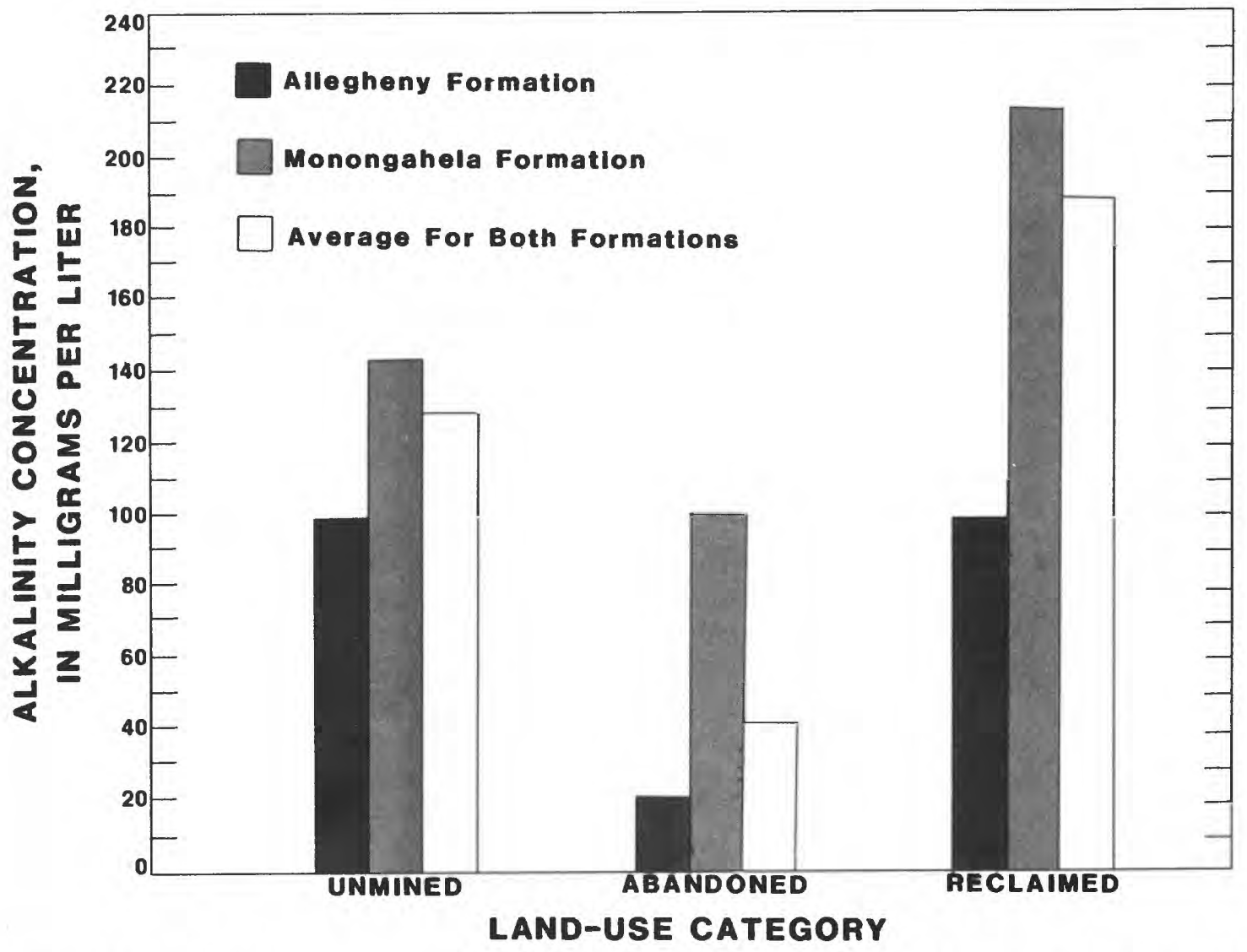

FIgure 3.3.4-1 Average alkalinity concentrations (data from Pfaff and others, 1981 ). 


\subsection{SURFACE-WATER QUALITY (Continued) \\ 3.3 RESULTS OF WATER-QUALITY ANALYSES (Continued) 3.3.5 Iron concentration}

\section{IRON CONCENTRATIONS ARE NOT SIGNIFICANTLY DIFFERENT AMONG MINING CATEGORIES}

\section{Although most of the very high iron concentrations are found in abandoned-mine basins, ranges of concentrations for each mining category are too wide to be able to distinguish statistically significant differences between categories.}

Iron is one of the principal components of acid mine drainage, and iron hydroxide is acid mine drainage's most visible effect on streams. In basins where acid mine drainage is severe, iron hydroxide can be seen as a reddish-yellow solid that covers the beds and banks of streams.

Iron was present at all sites in the study area at concentrations ranging from $0.04 \mathrm{mg} / \mathrm{L}$ (milligrams per liter) in an unmined basin to $4,400 \mathrm{mg} / \mathrm{L}$ in an abandoned-mine basin. The highest concentrations of iron were found in streams with the lowest $\mathrm{pH}$ values, that is, the most acidic streams; iron is very soluble at low $\mathrm{pH}$.

Despite the appearance of the graph in figure 3.3.5-1, statistical analysis did not differentiate between iron concentrations for either mining category or geology. Although 88 percent of all large (greater than $10 \mathrm{mg} / \mathrm{L}$ ) iron concentrations were found in abandoned-mine basins, there were enough lower concentrations in these basins to preclude significant differences between mining categories.

The U.S. Environmental Protection Agency's (1976) suggested limit for iron in domestic water supplies is $0.3 \mathrm{mg} / \mathrm{L}$. Iron is not harmful to humans at this concentration; however, concentrations in excess of this can impart an objectionable taste to water and can stain plumbing fixtures and laundry. The suggested limit for freshwater aquatic life is $1.0 \mathrm{mg} / \mathrm{L}$ (U.S. Environmental Protection Agency, 1976). Pfaff and others (1981) found that iron concentrations in unmined basins commonly exceeded $0.3 \mathrm{mg} / \mathrm{L}$. 


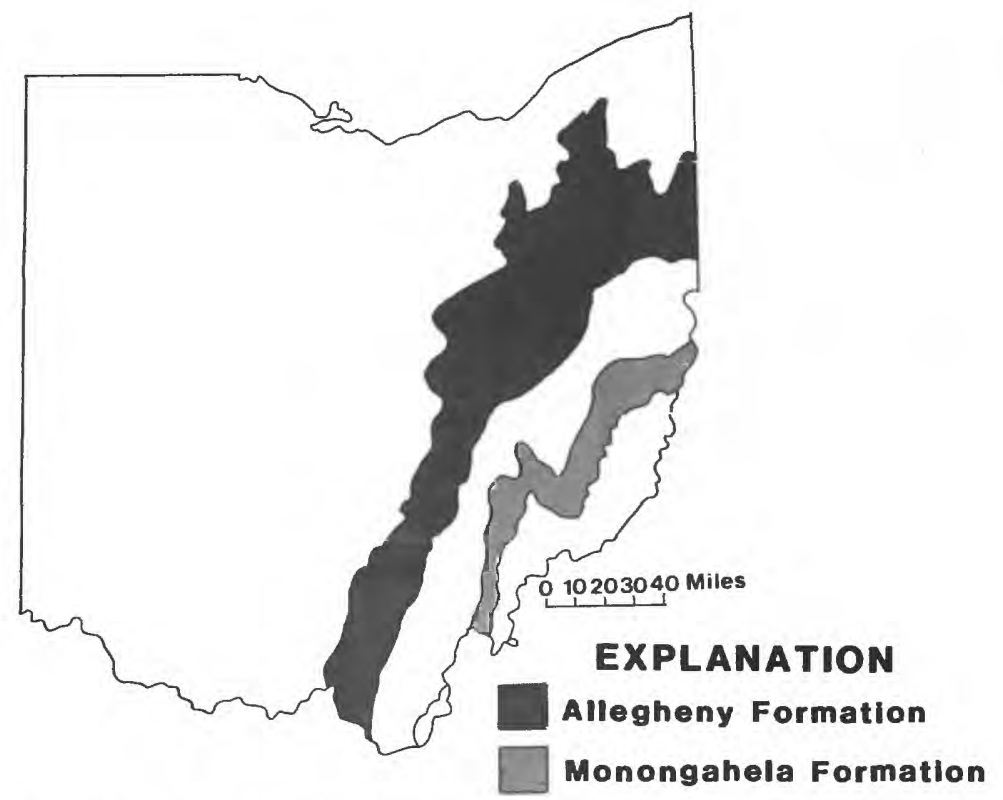

Approximate boundaries of Allegheny and Monongahela Formations.

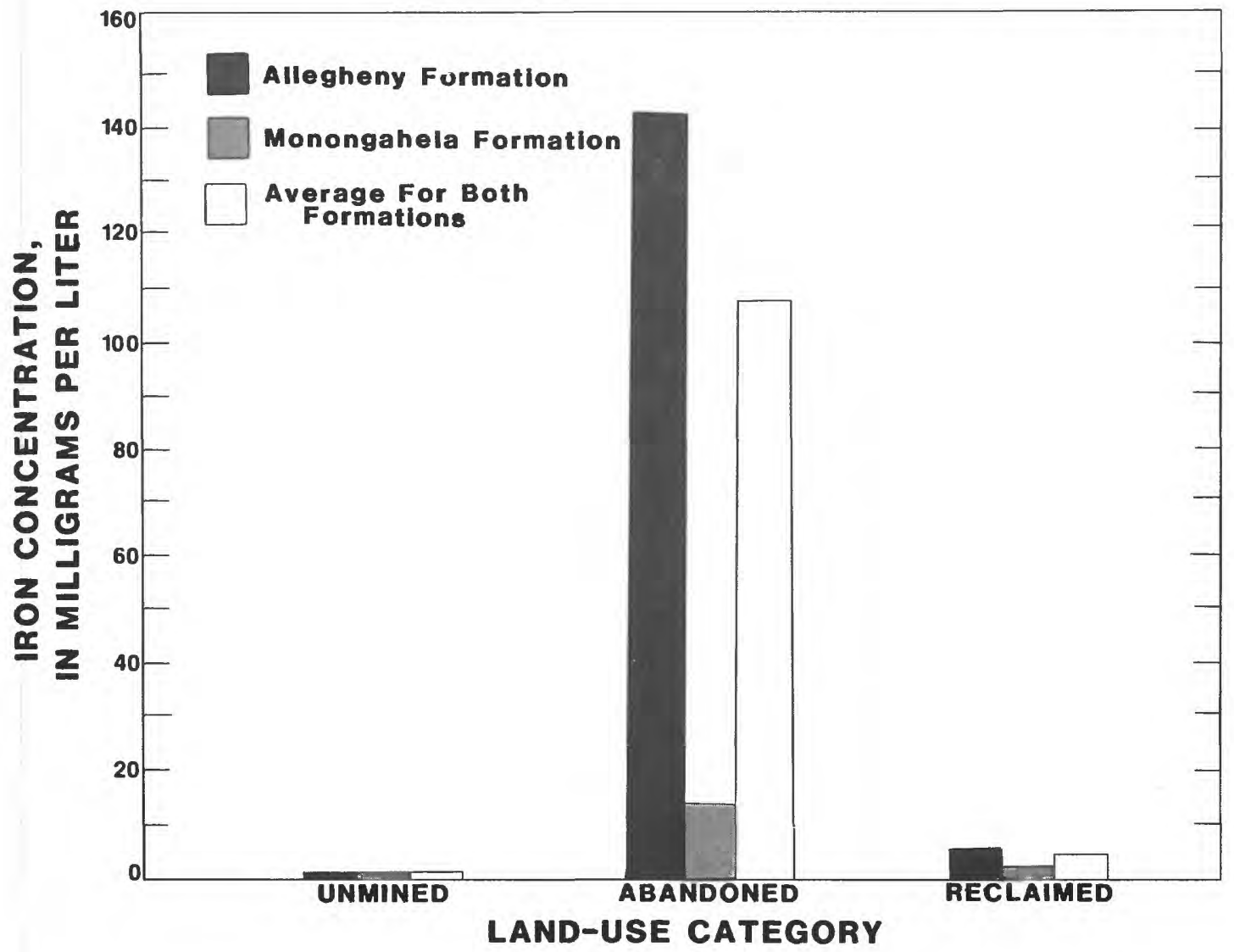

Figure 3.3.5-1 Average iron concentrations (data from Pfaff and others, 1981 ). 


\title{
3.0 SURFACE-WATER QUALITY (Continued) \\ 3.3 RESULTS OF WATER-QUALITY ANALYSES (Continued) \\ 3.3.6 Aluminum concentration
}

\section{HIGHER ALUMINUM CONCENTRATIONS ARE FOUND IN ABANDONED-MINE BASINS THAN IN UNMINED OR RECLAIMED BASINS}

\begin{abstract}
Aluminum concentrations were similar in unmined and reclaimed basins, however, the concentrations found in abandoned-mine basins were much higher.
\end{abstract}

Aluminum is the third most abundant element in the earth's crust; it is a principal component of clays. It is present in most natural waters at concentrations less than 0.5 milligrams per liter (Rainwater and Thatcher, 1960). As the pH of a stream decreases, aluminum concentration generally increases; where the $\mathrm{pH}$ is less than 4.0, high concentrations of aluminum are likely to be found.

Statistical analysis showed that aluminum concentrations in abandoned-mine basins were significantly higher than those of reclaimed and unmined basins, but that reclaimed and unmined basins were indistinguishable on the basis of aluminum. No differences were detected with respect to geology.

Concentrations of aluminum ranged from $0 \mathrm{mg} / \mathrm{L}$ (milligrams per liter) in two unmined basins to $490 \mathrm{mg} / \mathrm{L}$ in an abandoned-mine basin. Averages for each mining category were: Abandoned, 15.74 $\mathrm{mg} / \mathrm{L}$; reclaimed, $0.99 \mathrm{mg} / \mathrm{L}$; and unmined, $0.54 \mathrm{mg} / \mathrm{L}$ (fig. 3.3.6-1). Concentrations were highest at abandoned-mine sites because these were generally the sites having the lowest $\mathrm{pH}$.

The U.S. Environmental Protection Agency has not published limits for aluminum for domestic supplies or freshwater aquatic life. Aluminum in publicwater supplies has not generally been considered a public health problem, as people ingest significant quantities of aluminum (perhaps 10 to 100 milligrams per day) in a normal diet. Very little of the ingested aluminum is absorbed by the body (McKee and Wolfe, 1962, p. 130). 


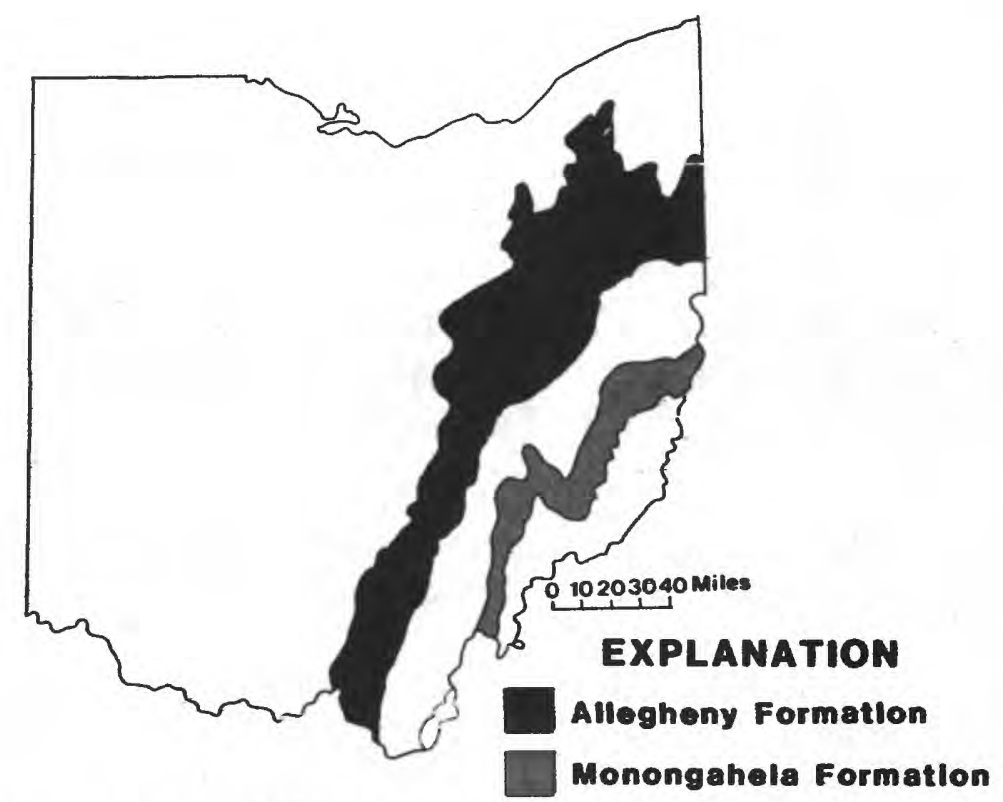

Approximate boundarles of Allegheny and Monongahela Formations.

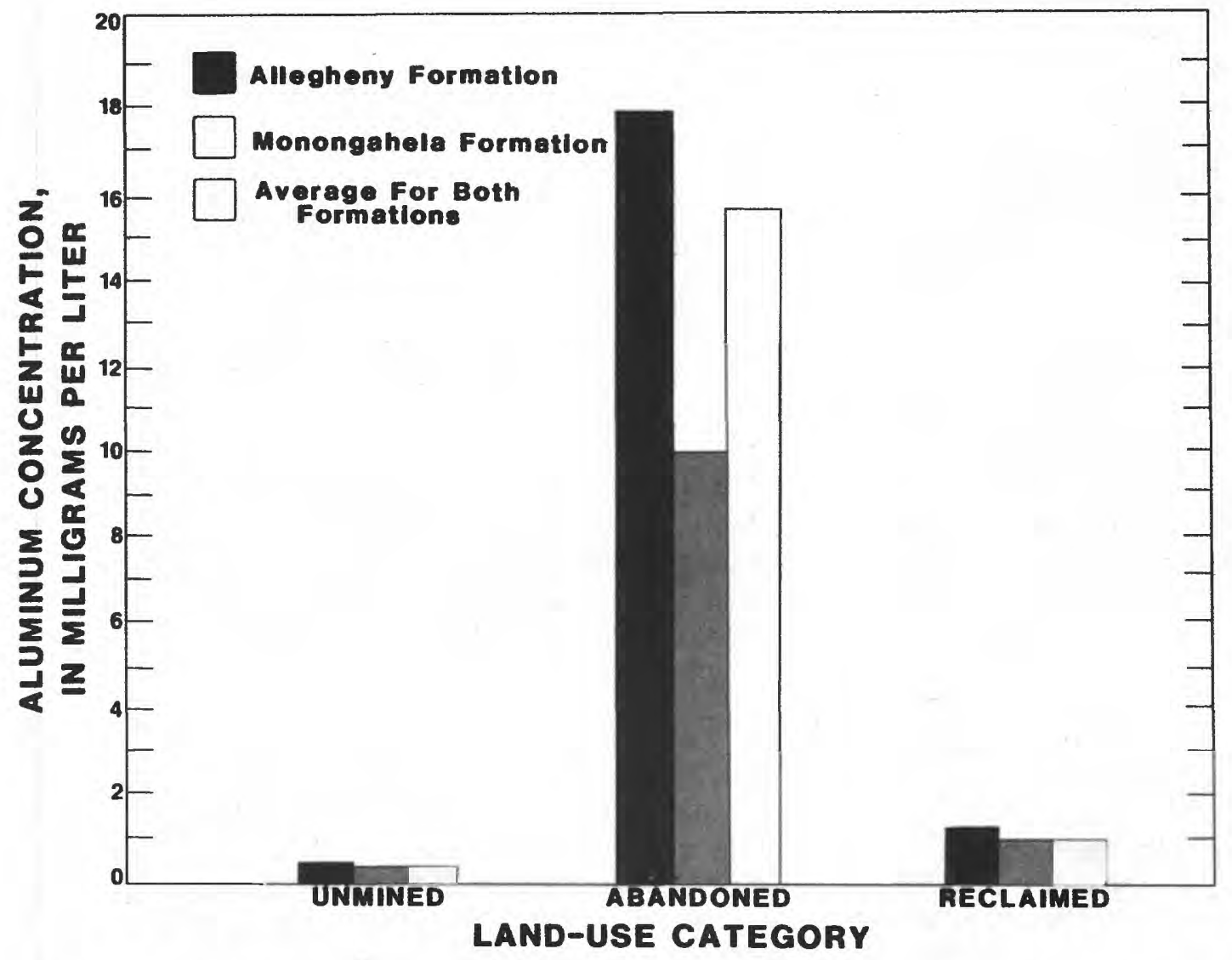

Figure 3.3.6-1 Average aluminum concentration (data from Pfaff and others, 1981 ). 


\title{
4.0 SUMMARY AND CONCLUSIONS
}

\section{MINING AFFECTS pH, SPECIFIC CONDUCTANCE, ALKALINITY, AND CONCENTRATIONS OF ALUMINUM AND SULFATE IN OHIO STREAMS}

\author{
Mining has significant effects on five water-quality characteristics; reclamation, however, \\ returns only aluminum and $\mathrm{pH}$ to levels near those of unmined basins.
}

Statistical analysis of water-quality data from 150 sites in eastern Ohio showed that $\mathrm{pH}$, specific conductance, alkalinity, and concentrations of aluminum and sulfate are affected by coal mining in Ohio; average values for all these characteristics were significantly different between unmined and abandoned-mine basins. Sulfate concentrations and specific conductance are the best indicators that coal mining has taken place within the drainage basin of a stream; even if basins are reclaimed, these two characteristics are significantly higher than for unmined basins. Sulfate concentrations greater than 250 milligrams per liter and specific conductances greater than 800 micromhos per centimeter generally were due to mining disturbances.

Reclamation returned $\mathrm{pH}$ and aluminum to levels near those of unmined basins, but reclamation increased alkalinity compared to unmined basins. Alkalinity and $\mathrm{pH}$ also showed significant differences with respect to geology. Streams in basins underlain by the Monongahela Formation contain more bicarbonate, which raises alkalinity and $\mathrm{pH}$, than do streams in basins underlain by the Allegheny Formation.

Approximately 88 percent of all iron concentrations greater than 10 milligrams per liter are in abandoned-mine basins. There were enough low concentrations in these basins, however, that significant differences in iron were not found on the basis of landuse categories. The averages for the properties and constituents discussed above are summarized in table 4.0.1.

The results of the assessment are important for two reasons. First, the differences noted between land-use categories for average values of $\mathrm{pH}$, specific conductance, alkalinity, sulfate, and aluminum are significant at the 95-percent confidence level-that is, there is only a 5-percent chance that statistical methods have indicated a difference where one does not actually exist. This is strong evidence (but not proof, in the strictest sense) that abandoned mines and mine reclamation have consistent, predictable effects on these water-quality characteristics in Ohio's coal region.

Second, the relationships of land use to water quality revealed by this study could potentially be used to streamline water-quality sampling programs and make it easier to identify mined lands in need of reclamation. Present procedures for determining water quality in mined areas can be expensive, as can the field work needed to determine if mining has ever taken place in a particular basin. The results reported by Pfaff and others suggest that sampling for the right combination of just a few characteristics would not only allow investigators to characterize water quality of a basin accurately, but also would enable them to determine whether the dominant land-use types were unmined, abandoned-mine, or reclaimed.

This and other scientific reports on the relationships among mining, reclamation, and water quality constitute an important body of technical information. Such information has been and will continue to be weighed against economic, social, and political considerations as State and Federal policymakers develop and implement reclamation programs for Ohio's coal region. 


\subsection{SELECTED REFERENCES}

Bownocker, J. A., 1981, Geologic map of Ohio: Ohio Department of Natural Resources, Division of Geological Survey, map, scale 1:500,000. .

Brant, R. A., and DeLong, R. M., 1960, Coal resources of Ohio: Ohio Department of Natural Resources Division of Geological Survey Bulletin 58, p. 21-28.

Brown, Eugene, Skougstad, M. W., and Fishman, M. J., 1974, Methods for collection and analysis of water samples for dissolved minerals and gases: U.S. Geological Survey Techniques of WaterResources Investigations, Book 5, Chap. A1, $160 \mathrm{p}$.

Camplin, Paul, 1965, Strip mining in Kentucky: Kentucky Department of Natural Resources, Strip Mining and Reclamation Commission, $56 \mathrm{p}$.

Cassidy, S. M., ed., 1973, Elements of practical coal mining: Baltimore, The American Institute of Mining, Metallurgical and Petroleum Engineers, $614 \mathrm{p}$.

Collins, Horace R., 1976, Coal production in Ohio-1800-1974: Ohio Department of Natural Resources, Division of Geological Survey Information Circular 44, $33 \mathrm{p}$.

Friedlander, Gordon, 1981, Strip mining and the utilities: Electrical World, v. 195, no. 5, p. 67-89.

Hem, J. D., 1970, Study and interpretation of the chemical characteristics of natural water (second edition): U.S. Geological Survey Water-Supply Paper 1473, $363 \mathrm{p}$.

Lapedes, D. N. (ed.), 1978, McGraw-Hill Dictionary of Scientific and Technical Terms (second edition): New York, McGraw-Hill, 1771 p.

La Roque, Aurele, and Marple, M. F., 1955, Ohio fossils: Ohio Department of Natural Resources Division of Geological Survey Bulletin 54, 152 p.

Langbein, W. G., and Iseri, K. T., 1960, Manual of Hydrology, Part 1; General surface-water techniques - General introduction and hydrologic definitions: U.S. Geological Survey Water-Supply Paper 1541-A, $29 \mathrm{p}$.

McKee, J. E., and Wolf, H. W., 1963, Water quality criteria: California State Water Resources Control Board Publication 3-A, 548 p.
Newman, W. L., 1978, Geologic Time: U..S. Geological Survey popular leaflet.

Noble, A. G., and Korsok, A. J., 1975, Ohio-an American heartland: Ohio Department of Natural Resources, Division of Geological Survey Bulletin 65, p. 27-33.

Ohio Board on Unreclaimed Strip Mined Lands, 1974, Land reborn: $91 \mathrm{p}$.

Ohio Department of Natural Resources, Division of Geological Survey, 1983, Report on Ohio mineral industries, 1981: $71 \mathrm{p}$.

Ohio Division of Mines, 1978, Annual Report: Ohio Department of Industrial Relations, $118 \mathrm{p}$.

Peattie, Roderick, 1923, Geography of Ohio: Ohio Department of Natural Resources Division of Geologicai Survey Bulletin 27.

Pfaff, C. L., Helsel, D. R., Johnson, D. P., and Angela, C. G., 1981, Assessment of water quality in streams draining coal-producing areas in Ohio: U.S. Geological Survey Water-Resources Investigation Open-File Report 81-409, 104 p.

Rainwater, F. H., and Thatcher, L. L., 1960, Methods for collection and analysis of water samples: U.S. Geological Survey Water-Supply Paper 1454, $301 \mathrm{p}$.

Simon, J. A., and Hopkins, M. E., 1973, Geology of coal, in Cassidy, S. M., Elements of practical coal mining: Baltimore, The American Institute of Mining, Metallurgical and Petroleum Engineers, p. 11-39.

Tourbier, J. T., and Westmacott, Richard, 1980, A handbook for small surface coal mine operators: U.S. Office of Surface Mining, $130 \mathrm{p}$.

U.S. Environmental Protection Agency, 1973, Processes, procedures, and methods to control pollution from mining activities: EPA-430/9-73-011, $390 \mathrm{p}$.

1976, Quality criteria for water: $256 \mathrm{p}$.

1977. National interim primary drinking water regulations: EPA-570/9-76-003, $159 \mathrm{p}$. 